\title{
1 Exploring extreme rainfall impacts on flow and turbidity dynamics in a steep,
}

2 pristine and tropical volcanic catchment

3 Vanessa Solano-Rivera ${ }^{1}$, Josie Geris ${ }^{2}$, Sebastián Granados-Bolaños ${ }^{1}$, Liz Brenes-Cambronero ${ }^{3}$,

4 Guillermo Artavia-Rodríguez ${ }^{1}$, Ricardo Sánchez-Murillo ${ }^{4}$, ${ }^{*}$ Christian Birkel $^{1,2}$

$6{ }^{1}$ Department of Geography and Water and Global Change Observatory, University of Costa Rica, 72060 San José, Costa Rica.

$8{ }^{2}$ Northern Rivers Institute, University of Aberdeen, AB24 3UF, Aberdeen, Scotland.

$9{ }^{3}$ ReBAMB, Sede de Occidente, University of Costa Rica, 2060 San José, Costa Rica.

$10{ }^{4}$ Stable Isotope Research Group, National University of Costa Rica, Heredia, Costa Rica.

11 *Corresponding author: christian.birkel@ucr.ac.cr

13 Manuscript

14 Abstract: 277 words

15 Word count: 7164 (without abstract, figure and table captions and reference list)

16 Number of figures: 9 (colour)

17 Number of tables: 3

18 Supplementary material: Figure S1

19 Abstract

20 Tropical volcanic landscapes are important because of the short timescales $(<$ years) over which

21 they transform. Sediment sources, availability and transport can be highly dynamic, but our

22 understanding of these is limited by a lack of data in these complex environments, especially with

23 regards to extreme events. To investigate the responses to extreme rainfall events in particular, we

24 conducted extensive monitoring in a pristine tropical rainforest catchment $\left(3.2 \mathrm{~km}^{2}\right)$, located in the

25 Volcanic Cordillera of Tilarán, Costa Rica. We established high temporal resolution hydro- 
meteorological and turbidity monitoring from June 2015 to July 2016. This included a record

27 convective rainfall event in August 2015 which resulted in an estimated $>50$ yr return period flood

28 event. We also surveyed hillslope soils, landslides, and sediments of the river network, to

29 characterize sediments before and after the extreme event. Our results suggested that rainfall

30 events activated surface flow pathways with associated mobilization of material. However, erosion

31 processes were mostly linked to finer material (sand, silt) properties of the soils that developed on

32 more highly weathered bedrock. The single extreme event (return period > 50 years) had an

33 overriding impact on the general sediment dynamics. Recovery in the form of fine material

34 transport and associated hysteresis took only about three months. We conclude that the combined

35 use of high-temporal resolution monitoring with spatially distributed surveys provided new

36 insights for the initial assessment into the fluvial geomorphology and transport dynamics of steep,

37 volcanic headwater catchments in the humid tropics with potential to establish more complete time

38 scales of land-forming processes. This work can build the foundation for more complete

39 monitoring using radioisotopes as a tool to fingerprint the sediment origin and composition.

40 Keywords: Tropics; Costa Rica; turbidity; erosion; Volcanic and fluvial geomorphology;

41 Extreme rainfall events, ReBAMB.

\section{Abbreviations:}

43 AWI7d- Antecedent wetness 7 days (mm)

44 M- Precipitation magnitude $(\mathrm{mm})$

45 Imax- Maximum intensity $(\mathrm{mm} / \mathrm{h})$

46 P_Qlag- Lag between the peaks of precipitation and discharge (h)

47 Range- Turbidity range from beginning to the event peak (NTU)

48 P_NTUlag- Lag between the peaks of precipitation and turbidity (h)

49 NTU_Qlag- Lag between the peaks of discharge and turbidity (h) 
50 Qrange Discharge range from beginning to the event peak $\left(\mathrm{m}^{3} / \mathrm{s}\right)$

\section{1. Introduction}

53 Tropical ecosystems experience an accelerated land use change (Foley et al., 2005) and are climate

54 change hot spots, particularly in Central America (Giorgi, 2006; González et al., 2017). Despite

55 the deforestation ban in Costa Rica which increased the national forest cover over the last 30 years

56 (Fagan et al., 2013), there is a prevalent trend towards deforestation in the wider region. The

57 associated impacts of these changes on hydrological processes and sediment dynamics in the

58 tropics has received much interest (Chappell et al., 2004; Bonell and Bruijnzeel, 2005). An

59 increasing number of studies have examined sediment dynamics across a wide range of catchments

60 (Fryers, 2013; Buendia et al., 2015). However, these studies have focussed mostly on

61 anthropogenically-impacted catchments (e.g. agriculture), where human disturbance accelerates

62 the natural process of erosion-transport-deposition (Walsh et al., 2011). Research conducted in

63 undisturbed forested areas is limited (see Zhang et al., 2010 as an exception and a global review

64 by Zimmermann et al., 2012), particularly in tropical forests with a geomorphology of volcanic

65 origin (see Muñoz-Villers and McDonnell, 2012, for an example with emphasis on rainfall-runoff

66 dynamics) where the natural dynamics of erosion and deposition processes are mostly unknown.

67 Furthermore, the tropics are generally characterized by high rainfall rates (Chang and Lau, 1983),

68 which - even under undisturbed vegetation cover - can result in surface flow, erosion and

69 subsequently naturally high sediment loads (Thomas, 1994). In such catchments, the erosion-

70 transport-deposition dynamics tend to be flashy and variable due to the heterogeneity of the climate

71 and the material properties of the soils and bedrock. The soil characteristics with e.g. low hydraulic

72 conductivity, as observed in a lowland rainforest catchment in Panamá, importantly influence the 
73 runoff generation processes with surface flow as the most prominent erosion mechanism

74 (Zimmermann et al., 2012).

75 Headwater systems globally amount to almost $80 \%$ of delivered water and transported substances

76 to rivers (Downing et al., 2012), but remain largely unmonitored. Within the tropics, volcanic

77 landscapes are of specific interest because of the short timescales (< years) over which they

78 transform (Wohl et al., 2012). This may cause severe consequences for downstream water users

79 (e.g. hydropower, drinking water, irrigation, and other ecosystem services). Understanding the

80 formation and evolution of volcanic landscapes in the tropics therefore involves an analysis of the

81 effects of intense and prolonged rainfall events on sediment dynamics and hydrological processes

82 at the event scale. Sediment mobilization can be (initiated) via:

83 a) shallow landslides and debris flows due to the saturation of the soils contributing material to the

84 streams,

85 b) laminar erosion on the hillslopes connected to the stream due to surface runoff even under

86 pristine forest cover and

87 c) the transport dynamics and erosion of the stream, banks and streambed itself.

88 However, a major challenge in both geomorphology and hydrology is reconciling the disparity

89 between small scale measurements with larger spatial and temporal scale processes (Bracken et

90 al., 2015). One way to assess the integrated response of the system at catchment scales is by linking

91 spatially distributed point scale measurements to high temporal resolution measurements in the

92 stream (Hancock and Lowry, 2015). Alternative approaches include measurements in nested

93 catchments such as by López-Tarazón and Estrany (2016) in the Mediterranean untangling the

94 drivers of sediment transport and their temporal characteristics. Similarly, Mills and Bathurst 
95 (2015) successfully developed a predictive suspended sediment load relationship with spatially

96 distributed catchment characteristics and sediment sources in the UK. However, long-term

97 catchment studies in the tropics are rare (see exceptions from Puerto Rico reported by Shanley et

98 al., 2011 and Thailand by Ziegler et al., 2014), despite that small-scale and detailed measurements

99 may lead to insights into the longer-term landscape forming processes of steep, tropical volcanic

100 catchments and the role extreme events might play.

101 In Costa Rica, Krishnaswamy et al. (2001a) found that suspended sediment transport was linked

102 to climate dynamics and land use disturbances in a large $\left(\sim 5000 \mathrm{~km}^{2}\right)$ heterogeneous catchment.

103 In addition, Calvo (1998) attempted to model suspended sediment yields for various larger

104 catchments and found that rainfall erosivity and land use were important drivers of sediment

105 transport. Jansson (2002) explored sediment origin using hysteresis analysis in a meso-scale

106 catchment draining the Caribbean in central Costa Rica. However, these studies followed a

107 relatively coarse temporal resolution (roughly monthly and few events in the case of Jansson,

108 2002) sampling of suspended sediments, so that the highly dynamic nature of processes during

109 events could not be captured. Following previous larger-scale efforts (e.g. Krishnaswamy et al.,

110 2001b), here, via intense monitoring, we aimed to gain more insights into the sediment transport

111 dynamics in humid tropical volcanic landscapes, with a specific focus on exploring responses to

112 extreme rainfall events. The monitoring included high temporal resolution turbidity, hillslope soil

113 erosion, material properties of soil and sediments, and hydrometric data collected over one

114 hydrological year in the San Lorencito catchment (a $3.2 \mathrm{~km}^{2}$ tropical pristine headwater catchment)

115 in the Volcanic Cordillera of Tilarán, Costa Rica. Using field and laboratory data and statistical

116 analyses, this study is one of the first in humid tropical volcanic environments that explores when,

117 how and where sediment transport is generated associated with hydrological processes and 
118 catchment responses to intense rainfall events, within the possibilities of a complex and logistically

119 challenging field site. We also tested the utility of turbidity as an indicator of suspended sediment

120 loads in a highly dynamic, volcanic catchment for a relatively short measurement period. The

121 specific objectives were to:

122 (i) monitor and analyse the stream response and subsequent turbidity dynamics to rainfall 123 inputs at high temporal resolution,

124 (ii) characterise the impact of an extreme event on the rainfall-runoff-turbidity and sediment relationship, fluvial geomorphology, and the subsequent recovery of the system,

(iii) explore how in-stream dynamics are linked to hillslope sediment sources, their connectivity to the stream, and potential changes to sediment sources induced by extreme events.

\section{$131 \quad 2$. Study area and methods}

\section{$132 \quad$ 2.1. Catchment characteristics}

133 The humid tropical San Lorencito headwater catchment drains an area of $3.2 \mathrm{~km}^{2}$ towards the

134 Caribbean Sea in the northern mountainous area of Costa Rica known as Cordillera de Tilarán

135 (Figure 1). The catchment is located in the Biological Reserve Alberto Manuel Brenes (ReBAMB),

136 a protected area with restricted access only for research. Land cover involves a typical primary

137 montane rainforest with negligible human intervention (Figure 1e). The most prominent tree

138 species are Elaegiaux panamensis and Ocotea morae, palmito (Iriartea deltoidea) and various

139 types of higuerones (Ficus spp.) (Salazar-Rodriguez, 2003). 
140 The geology is composed of tertiary volcanic rocks (5-9 million years), mainly from extrusive 141 materials such as basalts, andesites, and pyroclastic flow deposits typical of violent volcanic

142 activity during the younger Miocene Epoch (Bergoeing, 2007) from a nearby emission source in

143 the upper extreme of the catchment (Figure 1b). The morphology of the catchment is characterized 144 by steep slopes (> $30 \%$ ). The high annual rainfall is around $3 \mathrm{~m} / \mathrm{yr}$ with around $2 \mathrm{~m} / \mathrm{yr}$ of discharge 145 (Table 1). The main stream follows a normal fault line (Figure 1b) resulting in two slightly 146 different main hillslopes. The northern or left hillslope (B, upstream view) shows on average more 147 basalt and more andesitic mineralogy than on the southern or right hillslope (A, Figure 2). Hillslope 148 A is also on average less steep and deeper soils developed compared to those on hillslope B. The 149 soils originating from hillslope A were characterized by loamy and sandy loam particle size, while 150 the soils from hillslope B had less sandy particles and showed some presence of clay $(<30 \%)$. 151 Soil characteristics are related to the volcanic geomorphology of the catchment with less 152 developed, coarse textured Entisols or alluvial soil profiles near the stream. Closer to the hilltops 153 deeper Andisols (> $1 \mathrm{~m}$ ) with higher organic matter content (> $20 \%$ ) and almost permanent 154 saturation can be found. Remnants of volcanic ash in the upper profiles are common $(0-0.5 \mathrm{~m})$. 155 More information on catchment characteristics and the hydrology of the study site can be found in 156 Dehaspe et al. (2018).

157 The climate is characterized by a constantly high humidity close to $100 \%$ throughout the year 158 with a prolonged rainy season during the months from May to December and a short dry season 159 from January to April. Nevertheless, rain events are common throughout the year (Figure 1d). The 160 study area is situated at the continental divide and is predominantly under the influence of north161 eastern trade winds that are responsible for the influx of humidity. The latter in combination with 162 local, intense convective rainstorms generate very high rainfall rates well exceeding $40 \mathrm{~mm} / \mathrm{h}$ 
163 leading to a rapid stream response. Deviations from normal weather patterns are introduced by

164 frontal systems from the northern hemisphere winter, indirect effects of hurricanes and the El Niño

165 Southern Oscillation (ENSO) resulting in either increased or less rainfall (Birkel et al., 2016).

166 The San Lorencito stream is highly dynamic and bed materials are generally composed of volcanic

167 angular and sub-angular boulders disposed in large banks along the riverbed. The fluvial

168 geomorphology is dominated by step-pool features with some cascades (Figure 2A and C) and

169 characterized by the occurrence of frequent landslides (Figure $2 \mathrm{G}$ ) that deposit materials along

170 fluvial terraces (Figure 2F). Stream morphology is also affected by erosion that removes material

171 from the banks and riverbed. Minor alluvial fans can be found along the stream tributaries with

172 available large boulders and sediments to be transported in extreme conditions (Figure 2E).

174 2.2. Field Measurements and Laboratory Analysis

175 In-situ sensors measured turbidity (Global Water WQ730, NTU) and water level (Global Water

176 WL400-015-025) in an accessible and relatively protected section at the outlet of the San Lorencito

177 catchment over one year from June 2015 to July 2016. Sensors were placed within a 30kg steel

178 cage and PVC tubes for protection and routinely cleaned and calibrated. Data were stored every 5

179 minutes using a Global Water GL-500 logger. Meteorological data (rainfall, temperature,

180 humidity, radiation, pressure, wind direction and speed) were measured using a Davis Vantage Pro

181 Plus 2 station (MS1) programmed to 30-min time steps in a cleared spot located $1 \mathrm{~km} \mathrm{NE}$ outside

182 the study catchment (Figure 3). It is well known that both sloping ground (e.g. Sharon, 1980) and

183 canopy interception (e.g. Loescher et al., 2002) can introduce complexity and variability in the

184 observations of rainfall. To assess the extent to which the complete but single rainfall records of 
185 the meteorological station could be used for this study, we therefore initially explored the effects 186 of spatial variability and altitudinal gradients (total elevation gradient is 460m). For this, 187 throughfall measurements (HOBO rain gauges) were taken at different times during the rainy 188 season from June to December 2015 at two locations: one close to the stream (at $890 \mathrm{~m}$ a.s.1) and 189 on the left hilltop at $1232 \mathrm{~m}$ a.s.1 (Figure 2 - MS2 and MS3, respectively). We found that 190 throughfall at MS2 and MS3 and gross precipitation measured at the meteorological station 191 followed identical event timings in terms of peak rainfall with slight differences in measured 192 volumes $(<10 \%)$ due to the intercepting vegetation. No significant precipitation elevation gradient 193 was detected over the relatively short distance that concerns the study site and we do not show this 194 preliminary analysis here. Therefore, we used the continuous measurements of gross rainfall at the 195 meteorological station for further event analysis.

196 Throughout the entire monitoring period, manual discharge gaugings (salt dilution and current 197 meter) were done approximately every 3 weeks and on an occasional event-basis. The difference 198 between both measurement techniques was below $10 \%$ of absolute gauged streamflows. These 199 gaugings were used in the construction of a rating curve that converts measured water level into 200 discharge $\left(\mathrm{m}^{3} / \mathrm{s}\right)$ (Figure 4). During very high flows (at levels $>0.8 \mathrm{~m}$ ), overbank flow occurred. 201 We therefore applied a separate rating curve for these higher levels by applying Manning's 202 equation to events with recorded flood marks (four in total). We tested the sensitivity of the 203 resulting discharge estimate by varying the Manning coefficient $n$ for mountain streams with 204 cobbles and large boulders in between a range of 0.04 to 0.07 (Chow, 1959) reported as uncertainty 205 bounds. The maximum discharge was reconstructed for the four largest events and the highest 206 event of the monitoring period, at 10-12 August 2015, with an estimated $50 \mathrm{yr}$ return period. The 207 latter return period is a rough estimate to provide some longer-term context based on the highest 
208 recorded rainfall amount and intensity since on-site meteorological measurements began in 2008.

209 Further, the changes to the stream channel were not observed by long-term staff members since

210 the establishment of the research station in 1976. Most importantly, riparian trees (higuerones,

211 Ficus spp.) of $30 \mathrm{~m}$ height estimated by plant physiologists to exceed 100 years of age were

212 removed by the extreme event. As evidenced by the consistency in gaugings in Figure 4, the

213 channel geometry itself did not change after this large event, so that the same rating curve is applied

214 consistently in time. Uncertainty in the rating curve is highest for the high discharges due to a

215 strong non-linearity induced by the extreme event that exceeds 100-fold the second largest event

216 (Figure 4 inlet). All data were directly used for analysis without gap filling in case of sensor failure.

217 Turbidity measurements were recorded in Nephlometric Turbidity Units (NTU). Continuous, at

218 least monthly, maintenance and cleaning prevented sensor failure. In addition, there was little

219 possibility for debris build-up around the optical sensor due to the high flow velocities $(>2 \mathrm{~m} / \mathrm{s})$

220 during events. Stream water samples $(n=23)$ were manually taken using a standard DH-48

221 sediment sampler across a range of level and turbidity conditions in an attempt to relate the mass

222 of sediments to the NTU data. These stream water samples were processed to obtain the total of

223 suspended and dissolved sediments (American Public Health Association, 1999). The spatial

224 variability in sediments was assessed by collecting manual sediment samples in seven different

225 tributaries on both hillslopes (A, B) and in the main stream (Figure 3). To further determine the

226 impact of main rainfall events, this was done before and after the $50 \mathrm{yr}$ return period flood event.

227 All samples were completely dried for 3 hours at $105{ }^{\circ} \mathrm{C}$, treated with $\mathrm{H}_{2} \mathrm{O}_{2}$ to remove organic

228 material and then washed and dried again. The sediments were processed to obtain the particle size

229 distribution curve using a set of 19 (Fisher Scientific) sieves varying from 8 to $0.05 \mathrm{~mm}$ and the

230 Retsch As200 sieve shaker. The material remaining in each sieve was weighed and visualized as 
231 cumulative percentages. The $0.25 \mathrm{~mm}$ quartz diameter was selected for a morphoscopic analysis

232 conducted using a Meiji PBH Stand stereoscope (Tricart, 1965). Landslides were mapped after the

233 extreme event and the dimension documented with digital imagery. The landslide volumes were

234 derived from a post-event interpretation of georeferenced photographs converted into 3D imagery

235 using the Agisoft Photoscan software.

236 To assess stream sediment in the context of potential source areas, 26 soil samples $(0$ to $30 \mathrm{~cm}$

237 depth) were taken at accessible sites across the catchment (Figure 3) and analysed for soil texture.

238 Eighteen samples were processed using the pipette method (Veas, 2009) at an earlier time and

239 eight samples using Bouyoucos method over the study period. Despite slight differences in the

240 analytical protocol, both methods provided comparable results using duplicate measurements for

241 comparison (Norambuena et al., 2002). The texture of the soils was determined using the USDA

242 textural triangle (Henríquez \& Cabalceta, 2012).

243 To monitor erosion and/or deposition of material on both hillslopes, at different altitudes and

244 slopes, soil movement was assessed using a total of 10 erosion pins following Hancock \& Lowry

245 (2015). The pins consisted of $60 \mathrm{~cm}$ length steel rods with a $>0.6 \mathrm{~cm}$ diameter and were painted

246 with anticorrosive yellow. They were inserted manually (site conditions allowing) without a

247 hammer (Hancock \& Lowry, 2015) as depth markers. Readings with an approximate error of 0.2

$248 \mathrm{~cm}$ were done monthly by the same person during the rainy season and during the dry season the

249 data were collected twice in January and once at the end of May after the rainy season 2016 started. 
252 We analysed the rainfall-runoff-turbidity dynamics of the study site for a range of different events,

253 which also included a major flood event during August 2015. The identification and definition of

254 an event considered in this study was done systematically and based on both precipitation and

255 discharge data. The start of precipitation indicates the beginning of an event, while the end of the

256 discharge recession curve defined the end of the event. To be able to clearly identify event

257 characteristics, we also imposed a threshold of a minimum water level change of $0.1 \mathrm{~m}$. Double-

258 peak runoff events were not detected.

259 Descriptive event statistics were used to explore 26 hydro-meteorological variables that 260 characterize the size, range, minimum, maximum, mean, magnitude, intensity, duration of rise and 261 recession and time lag of the precipitation-discharge-turbidity relationship of each selected event, 262 as well as the antecedent wetness conditions for 3, 7 and 30 days plus the time (hours) without 263 rainfall prior to an event. The hysteresis index of Zuecco et al. (2016) was applied using discharge 264 as the independent variable and turbidity as the dependent variable. Among many other hysteresis 265 indices available, the index by Zuecco, et al. (2016) is a dimensionless number allowing for 266 automatic and objective calculation of all the forms of possible hysteresis loops, sizes and 267 directions found here. The selected events were further separated into dry (January to April) and 268 wet (May to December) season and before and after the major event in August 2015 mainly due 269 to the climatic seasonality of the study site and the impact caused by the event.

270 Spearman rank correlation (r) and Principal Components Analysis (PCA) were applied to reduce

271 the number of environmental variables avoiding co-linearity as indicated by an $r>0.7$ and to search 272 for relationships that could potentially explain the rainfall-runoff-turbidity dynamics of the study 273 site (see Abbreviations of selected variables). Selected variables for correlation analysis were 274 additionally checked for co-linearity using the Variance Inflation Factor. Cumulative particle size 
275 distributions and the shape and oxidation level of sediment samples were used to examine spatial

276 variability across the main stem and tributaries before and after the major event in August 2015.

277 A Kruskal-Wallis test was applied to the sediment data to determine the statistical evidence of 278 significant changes associated to the rainy and dry season events, and the major flood event ( $R$ 279 core team, 2016).

281 3. Results

\section{3.1 Rainfall-runoff event and turbidity dynamics}

283 The study year was characterised by a record El Niño event (NOAA, 2016) resulting in lower than 284 average annual precipitation ( $2700 \mathrm{~mm} / \mathrm{yr}$, Table I). Despite the generally drier conditions on the 285 Pacific slope, the catchment locally received a record convective rainfall event in August 2015 286 resulting in a likely $>50 \mathrm{yr}$ return period flood event. A total of 29 rainfall events were selected 287 over the study year from 13/06/2015 to 13/06/2016 (Figure 5, Table II). From the 26 hydro288 meteorological variables, 8 (Table II, Abbreviations) were used to describe the temporal dynamics 289 of events explaining $92 \%$ of the total variance based on three Principal Components. The other 29018 variables mostly resuming initial and recession conditions of events were neglected due to $r>$ 2910.7 indicating co-linearity. Furthermore, the 8 selected parameters showed small effects of co292 linearity tested using the Variance Inflation factor resulting in values smaller than 6 for all cases.

293 Table II gives the full spectrum of events and analysed variables with the overall mean and 294 standard deviation.

295 As the hydrometerological conditions, in particular rainfall, are distinctly different for different 296 seasons (Figure 1), we first describe the rainfall-runoff and turbidity event dynamics for each wet 
297 and dry season cycle based on the typical climatic features of the study site. Out of the total 29 298 events, 25 occurred during the 2015 rainy season from June to December. During this rainy season, 299 the precipitation magnitude ranged from 2.8 to $132.3 \mathrm{~mm}$, with average rainfall duration of 5.4 300 hours. The turbidity increased up to a maximum value in almost half of the events. The median 301 time lag between the rainfall peak and maximum discharge was one hour. The median time lag 302 between the discharge peak and the turbidity peak was also 1 hour, while the median time between 303 the peaks of precipitation and turbidity was 2.5 hours (Figure 5), but generally lags followed a 304 normal distribution.

305 During the dry season 2016 (January-April) only two out of the 29 events were identified (Figure 306 5), despite more sporadic rainfall originating from the Caribbean. The magnitude of the two 307 precipitation events was 19.3 and $45.2 \mathrm{~mm}$ (for the first and second event, respectively). The 308 discharge range reported was from 0.4 to $0.8 \mathrm{~m}^{3} / \mathrm{s}$ and events lasted from 1.5 to 8.5 hours, while 309 the turbidity reached maximum values just once (Figure 5).

310 Likewise, also only two events were identified for the beginning of the rainy season in May 2016.

311 The magnitude $M$ of these precipitation events was $12.7 \mathrm{~mm}$ and $35.6 \mathrm{~mm}$ (Table II). The discharge 312 range reported was $1.1 \mathrm{~m}^{3} / \mathrm{s}$ and $1.7 \mathrm{~m}^{3} / \mathrm{s}$ respectively, while the turbidity reached relatively low 313 values in both events (Figure 5).

314 The runoff-turbidity data showed distinctly different hysteresis patterns for periods before the main 315 August 2015 event and during the recovery period. The events before August 2015 did show few 316 hysteresis patterns exhibiting a clockwise behaviour (Table II; Figure 6, first panel). From August 317 2015, all events did indicate hysteresis patterns of discharge versus turbidity with changing 318 clockwise and anti-clockwise loops (Figure 6, second and third panel). The most frequent 
319 hysteresis class according to the classification of Zuecco et al. (2016) was class 2 (clockwise,

320 increasing from initial values, but shape of an eight similar to event 3, second panel of Figure 6).

321 Apart from one class 6 and one class 5 event, no events that showed decreasing values from the

322 initial state were detected (class 7 and 8). The hysteresis behaviour also shifted from no time lag

323 to a relatively regular clockwise hysteresis including the major event in August (Figure 5, event

324 2) to a more chaotic anti-clockwise and eight-shaped hysteresis pattern, back to initial conditions

325 showing a clockwise hysteresis (Figure 6, event 4).

$327 \quad 3.2$ Impacts of an extreme event on the rainfall-runoff response and turbidity dynamics

328 During August 2015, two consecutive convective storms in less than 36 hours triggered an

329 estimated $50 \mathrm{yr}$ return period flood event. Antecedent rainfall was $24 \mathrm{~mm}$ over 7 days with

330 relatively dry soils before the first storm. On the first day, $132 \mathrm{~mm}$ of precipitation fell in less than

3314 hours with a maximum intensity of $40 \mathrm{~mm}$ in $30 \mathrm{~min}$ (Figure 5, event 2). This storm caused

332 water levels to rise $1.14 \mathrm{~m}$ with a discharge of around $25 \mathrm{~m}^{3} / \mathrm{s}$ in less than 3.5 hours, with

333 corresponding maximum turbidity levels of $>900$ NTU.

334 The second event occurred 14 hours after the previous storm, with soil saturation at a maximum,

335 and an additional accumulated $147 \mathrm{~mm}$ of rain in 4 hours. The maximum intensity was $77 \mathrm{~mm}$ in

336 less than 30 min resulting in a water level increase of up to $2.86 \mathrm{~m}$. The reconstructed flood peak

337 discharge based on flood marks using Manning's equation resulted in approximately $370 \pm 56$

$338 \mathrm{~m}^{3} / \mathrm{s}$. Turbidity levels were beyond $1000 \mathrm{NTU}$. A total accumulated rainfall of $279 \mathrm{~mm}$ revealed

339 (post-event field inspections) important morphological changes in the river network and over 15

340 landslides contributing an estimated $>100 \mathrm{~m}^{3}$ of material were identified along the stream. 
341 Tributaries were also intensively modified by incorporation of rocks, sediments, and vegetation

342 from the slopes (Figure 2E).

344 At the catchment level, the extreme flood event from August 2015 had some remarkable 345 consequences in terms of erosion and material transport (Figure 2A). The turbidity response to rain 346 events became slightly faster by around $30 \mathrm{~min}$ and reached maximum levels around 1000 NTU

347 with less precipitation after the flood event (Table II). The stream reached maximum turbidity 348 levels with on average lower precipitation inputs and rain intensity (Figure 5, event 3; Table II). A 349 Spearman rank correlation matrix was used to show differences in the time lag between the peaks 350 of precipitation, discharge and turbidity before and after the extreme event (Table III). The rainfall351 runoff dynamics before the extreme event were mostly related to antecedent conditions with a 352 significant correlation $(\mathrm{p}<0.1)$ of $A W I 7$ to discharge range (Qrange) of $\mathrm{r}=-0.66$ and rainfall 353 intensity Imax to Qrange with r $=0.65$. No significant correlations to lag times were detected prior 354 to the extreme event. The rainfall magnitude $M$ and Imax were only moderately correlated to the 355 rainfall-runoff lag $P_{-}$Qlag $(\mathrm{r}=-0.45)$ and the $P_{-}$NTUlag with $\mathrm{r}=-0.42$. The discharge range was 356 only moderately correlated to the turbidity range (NTUrange) $(\mathrm{r}=0.58)$.

358 After the extreme flood event, the antecedent conditions played no role on rainfall-runoff and 359 turbidity dynamics (Figure 7b). However, the rainfall magnitude $M$ was significantly correlated to 360 discharge $(\mathrm{r}=0.63, \mathrm{p}<0.05)$, and correlated to $P_{-}$Qlag $(\mathrm{r}=0.36)$ and rainfall and discharge, 361 turbidity lag time ( $\mathrm{r}=-0.4$ and -0.48 , respectively). The $P_{-} Q$ Llag was also significantly related to $362 Q \_$NTUlag with $\mathrm{r}=-0.54(\mathrm{p}<0.1)$ meaning the longer the rainfall-runoff response time is the 
363 shorter the runoff-turbidity response. After the event, the NTUrange was significantly correlated

364 to rainfall-turbidity lag time $(\mathrm{r}=0.56, \mathrm{p}<0.1)$ and discharge-turbidity lag time $(0.52, \mathrm{p}<0.1)$. A

365 Kruskal-Wallis test was applied to the 8 selected variables before and after the event. The results

366 of significance values p varied from 0.02 to 0.75 with the lag time of discharge to turbidity

367 resulting in the only significant change at the $95 \%$ level.

\subsection{Sediment sources and connectivity}

\section{Soil erosion measurements:}

371 Data recordings at the erosion pins showed that erosion was most prominently detected after the

372 major event in August 2015 with a maximum soil loss and deposits of over $10 \mathrm{~cm}$ at various sites.

373 However, the movement of materials in terms of erosion and deposition was variable across all

374 sites. Figure 8 indicates that most material was mobilised towards the end of the rainy season

375 (Figure 8 - M6, M7) with more accumulated rainfall. The erosion pins also showed that all sites

376 were characterised by gaining and losing conditions at some point across variable 9 to 35 degrees

377 steep slopes. Net erosion and net deposition was equally recorded at 5 sites each after the complete

378 1-year study period.

380 Figure 8 shows particle size distributions sampled from 1 week before and immediately 3 days 381 after the extreme event for the main stem and three to four tributary streams on both hillslopes A 382 and B (see Figure 3, sampling sites). The data for the main stem show that after the event, the 383 dominant particle size was generally smaller (mainly medium to course sand), than prior to the 
384 event (mainly coarse sand to gravel). Most tributaries (1A, 2A, 2B and 4B) showed a similar shift

385 in behaviour after the event. In contrast, the tributaries $3 \mathrm{~A}$ and $4 \mathrm{~A}$ accumulated coarser grained

386 material after the event, while the particle size distributions of tributaries $1 \mathrm{~B}$ and $3 \mathrm{~B}$ remained

387 largely the same. The granulometric curves identified mainly coarse particle sizes and only less

388 than $5 \%$ of all sediment samples collected were composed of silt. The latter material properties

389 might also be related to a slightly different tributary catchment morphology with more moderate

390 slopes (Figure 3) and finer material on hillslope A as opposed to coarser material on hillslope B.

Turbidity as an indicator of sediment loads:

393 Even though we focussed primarily on the temporal dynamics and potential processes that affect

394 the rainfall-runoff-turbidity behaviour, we also explored the use of turbidity as an indicator for 395 suspended sediment flux. Sediment particle size analyses from the 23 sampled storm events 396 indicated that all sand and coarser material in the samples corresponded with turbidity 397 measurements less than 200 NTU (Figure 9). Maximum turbidity exceeding 1000 NTU appeared 398 to be generated by finer dissolved particles (fine sands and silt). In absence of a significant amount 399 of superficially available clay particles (Figure 3c), the silt fraction was therefore responsible for 400 most of the turbidity generated (Figure 9). The sand fraction did not result in turbidity higher than 40150 NTU. However, silty material was less than $5 \%$ of the stream sediment composition (pre- and 402 post-event) and less than $30 \%$ of hillslope soils in the catchment. Even small amounts of silt 403 caused high turbidity independently of the total transported and sampled mass (Figure 9B). No 404 relationship between turbidity, suspended sediment concentration SSC (g/L) and discharge was 405 hence detected for construction of a reasonable rating curve during the study period (Figure 9A). 


\section{4. Discussion}

\section{$408 \quad$ 4.1 Characterizing rainfall-runoff-turbidity dynamics in tropical, volcanic catchments}

409 Among the first from humid tropical volcanic regions, our results showed that rainfall-runoff410 turbidity dynamics in the San Lorencito catchment are driven by hydroclimatic conditions and can

411 be further linked to heterogeneity in catchment characteristics and material properties of soils, and

412 bedrock. The climatic seasonality exhibited a high inter-event variability of the rainfall-runoff413 turbidity relationship particularly during the rainy season (Table II). The values of turbidity were

414 generally higher during the months from May to December (Table II). The runoff generation in 415 this steep and tropical setting causes - as can be expected (see Zimmermann et al., 2012) - a quick 416 runoff response to rainfall inputs in the order of 30 to $40 \mathrm{~min}$. However, there is an important 417 surface runoff generation component (Dehaspe et al., 2018) contrary to other studies from similar 418 systems that reported mostly sub-surface storm runoff generation (Muñoz-Villers and McDonnell, 419 2012). The rainfall-runoff response was unsurprisingly characterized by a significant relationship 420 with the antecedent wetness and storm characteristics such as rainfall intensity, while we detected 421 no significant rainfall-runoff-turbidity lags (Table III). However, the drivers of the rainfall-runoff 422 response were less dominated by the wetness state of the catchment and rainfall intensity 423 immediately after the impact of an extreme event that significantly modified the fluvial 424 geomorphology of the catchment. In addition, there were significant lag times in the turbidity 425 response to rainfall and discharge during that time. As such, we found complex discharge 426 turbidity hysteresis characteristics that shifted in shape and magnitude after the extreme event 427 (Table III - Figure 6). It is likely that this can be explained by shifts in the sediment sources, which 
428 in turn result in variations in the material itself (e.g. particle size, as shown by Cheraghi et al.

429 (2016)), but also the transport and delivery characteristics. Some events at the beginning of the

430 rainy season 2015 and before the extreme event did not show hysteresis, and others were

431 characterised by more complex temporal relationships (35\%). We observed mostly eight-shaped

432 hysteretic patterns (49\%) after the major flood event, while only $3 \%$ of events showed positive

433 (clockwise) hysteresis in contrast to López-Tarazón and Estrany (2016) from a Mediterranean

434 catchment and $13 \%$ showed negative (counter clockwise) hysteresis. Eight-shaped hysteresis

435 loops have previously been classified as less common and difficult to decipher in

436 geomorphologically different study areas (e.g. Hudson, 2003; Perks et al., 2015).

\subsection{The role of extreme events on sediment transport dynamics and fluvial geomorphology}

439 The transformation of fluvial systems mostly happens during extreme events, when equilibrium

440 river channel parameters and slope gradients may be disturbed and the thresholds controlling

441 fluvial or gravitational processes may be exceeded (Thomas, 1994). Among the hydro-

442 meteorological extreme events are those characterised by low exceedance probabilities of

443 precipitation and runoff. Even though our exceedance probability estimate of 50 years for the

444 August 2015 extreme event is rather uncertain, the empirical evidence suggested an extreme event

445 previously not observed for over 30 years. The orographic ascend of Caribbean trade winds

446 maintain a constant humidity most of the year with intense convective rainstorms originating from

447 the Pacific Ocean that caused the observed extreme runoff response and was the most intense

448 rainfall event of such a magnitude since measurements from 2008. The combination of both 449 precipitation mechanisms - a constant low intensity input of rainfall and intense convective storms 
450 - causes saturation excess overland flow with possibly associated laminar erosion (in contrast to 451 sub-surface stormflow generation on volcanic substrate identified by Muñoz-Villers and 452 McDonnell, 2012 in Mexico). Material movement on the hillslopes was clearly detected by the 453 erosion pins (Figure 8) particularly during the extreme event with soil losses and deposits of up to $45410 \mathrm{~cm}$.

455 Furthermore, the San Lorencito stream is controlled by a system of parallel normal faults with SW456 NE orientation; the direction in which the main channel drains (see Figure 1b, Denyer et al., 2003). 457 Tectonic joints on the volcanic rocks can be observed along the stream channel outcrops, which is 458 a pre-condition for exposed material and subsequent potential rapid incorporation into the stream 459 in extreme conditions. The extreme event described above created alluvial deposits (in parts areas $460>1800 \mathrm{~m}^{2}$ ) along the riparian zone and removed riparian vegetation (Figure 2A). In addition, 461 tributaries built up alluvial fans among deepening and widening of channels that caused the stream 462 to abandon a certain stream section (Figure 2E). The flood debris flow deposited large amounts of 463 material on abandoned fluvial terraces, and in other cases large deposits of young fluvial terraces 464 where eroded (Figure 2F). The latter type of material close to the main channel can be incorporated 465 and transported in short periods of time. Large rounded boulders such as in Figure 2F evidenced 466 the torrential behaviour and stream capacity of recent and historic extreme events. Therefore, the 467 study catchment can be characterised by an easy mobilisation of colluvial (mainly landslides and 468 laminar soil erosion) and alluvial material (stream bank and terrace erosion). Nevertheless, such 469 extreme events are part of the normal denudation on geological scales as suggested by deep scars 470 of mass movement on the hillslopes (evidence from the elevation model in Figure 1) and large 471 fluvial terraces (in parts with $\sim 20 \mathrm{~cm}$ of pedogenesis in Figure $2 \mathrm{~F}$ ) strongly support recent 472 Holocene torrential behaviour (Vargas, 1978). 


\section{$474 \quad$ 4.3 Sediment sources and hillslope-stream connectivity}

475 The periodic monitoring during sampling campaigns showed that the tributaries influence the

476 direction of streamflow and streambed incision (Figure 2E). The high rainfall in excess of $40 \mathrm{~mm} / \mathrm{h}$

477 in combination with variable geomorphological features of slope (e.g. on average lower slope on

478 hillslope A compared to B) and soils (Figure 3) and the vegetation density (Dehaspe et al., 2018)

479 dictated that the spatial variability of the catchment's connectivity was high (Fryers, 2013).

480 We also identified around 15 landslides that directly contributed colluvial material $\left(>100 \mathrm{~m}^{3}\right)$ into

481 the stream (Figure $2 \mathrm{G}$ and location in Figure 3). All rocks from the landslides were identified as

482 jointed andesites with different levels of profile weathering. After the stream lost transport capacity

483 during recession, the young incorporated material was deposited and readily available during

484 subsequent minor events causing high levels of turbidity for a prolonged time after peak flow (see,

485 e.g. Figure 5 - event 3). All the landslides identified during this study (Figure 3) occurred during

486 the rainy season. They also contributed an important amount of hillslope material into the stream

487 as part of or in addition to what was demonstrated by the monitored erosion pins (Figure 8).

488 Further evidence of hillslope-stream connectivity was found in identical levels of mineral 489 oxidation of sandy sediments recovered from soil, tributary and main stem sediment samples

490 (Figure S1). Seasonal patterns in sediment delivery, transport and deposition from the rainy season

491 into the dry season have been previously related to the rainfall regime with an increase in rainfall

492 events leading to an increased sediment yield (Thomas, 1994; Fryers, 2013). This is in agreement

493 with our results, even though we were limited by only using soil erosion measurements and

494 turbidity as an indicator for temporal dynamics in suspended sediments. Nevertheless, the transit 
495 of material from the hillslopes to the stream and within the channel appeared to occur throughout 496 the year, even though the frequency of rainfall events was less during the dry season. Such high 497 rainfall probability despite a climatic seasonality occurred similarly in other catchments on the 498 south Pacific slope (Birkel et al., 2016). During the dry season, drying soils allowed for relatively 499 more water to infiltrate (Figure $5 b$ - dry season rainfall events did result in very minor runoff 500 response), limiting the means for particles to erode from the hillslopes (Figure 8). The relatively 501 slow and limited sediment movement during the dry season was therefore dominated by readily 502 available material stored in the channel or from channel erosion since the channel sediments were 503 mostly sands with less than 5\% fine sandy aggregates (Figure 7) and these particles have a higher 504 settling velocity than the silts and clays originating from the hillslopes. Much of the hillslope 505 sediment movement with erosion and deposition was generated during the rainy season (Figure 8).

506 Sediment monitoring revealed two main types of sediment sources to the stream: Firstly, hillslope 507 material that was fed into the stream and tributaries through landslides, colluvial, and surface 508 erosion (similar to agricultural sites in the tropics, Duvert et al., 2010). Secondly, material deposits 509 that formed fluvial terraces and sediment banks in areas of low stream power. The sediment 510 particle distributions of the main stem and tributaries revealed that these were mostly coarse sand 511 and gravel particles ( 95\%). The fine sand and coarse silt particles represented less than $5 \%$ of 512 all sediment samples (see Figure 9). Sediments also exhibited an intense oxidation and weathering 513 of minerals (composed primarily by Phenocrystals such as plagioclase, augite, magnetite, 514 hornblende, quartz, olivine, biotite) similar to the dominating sand-silt soil samples as shown in 515 Figure 3 and S1. Similarities found in terms of morphology, particle size distribution, mineralogy 516 and oxidation of sands provided evidence of a hillslope - stream connection mainly due to erosion 517 caused by periodic surface runoff generation under more extreme rainfall (Figure 5). The most 
518 likely mechanism was saturation excess overland flow (Dehaspe et al., 2018), since soils

519 throughout the catchment have high infiltration capacities in excess of $200 \mathrm{~mm} / \mathrm{h}$ (in contrast to

520 Zimmermann et al., 2012). Under such extreme conditions, the dense forest cover does not play a

521 significant role on flood generating runoff mechanisms anymore (e.g. Birkel et al., 2012 from

522 another tropical volcanic Costa Rican catchment) that can also be associated to dominate material

523 transport in steep, tropical, volcanic catchments.

524 Contrary to other extra-tropical studies (e.g. Hudson, 2003; Rovira and Batalla, 2006), we 525 excluded a sediment exhaustion effect over the year. In the San Lorencito catchment, sediments 526 seemed to always be available and constantly moving, even though there was sediment depletion

527 over the dry season due to less rainfall events, increased infiltration of soils and the interception 528 effect of the vegetation cover on the hillslopes. It might well be that sediment availability is key 529 for rapid landscape transformations in the humid, volcanic tropics. However, more measurements 530 combining sediment fingerprinting similar to Duvert et al. (2010) and Martínez-Mena et al. (1999) 531 with efforts to quantify loads and their particle size distribution over a longer period will be 532 necessary to confirm these initial results.

\section{$534 \quad$ 5. Conclusions and outlook}

535 The challenge of working in tropical environments is partly reflected in less monitored catchments 536 on a global scale. For example, the recent global review on erosion and sediment dynamics in the 537 tropics by Labriere et al. (2015) did not include any study from Central America as an indication 538 of the under-represented monitoring in the region. Apart from the study by Jansson (2002) that

539 looked at event-scale SSC - Q hysteresis to determine sediment sources and the large-scale study 
540 by Krishnaswamy et al. (2001), there are to the best of our knowledge no systematic high-temporal

541 resolution studies reported in the literature. Ziegler et al. (2014) estimated the uncertainty in SSC

542 - Turbidity data from Thailand to be a major source of error in high load estimates over longer

543 periods. In that sense, sensor equipment with a large NTU range (0 to $10000 \mathrm{NTU}$ ) is needed to

544 capture the complete variability of runoff - turbidity events. Such events need to be accompanied

545 by high-resolution sediment sampling with an appropriate sampling strategy that captures the

546 complete particle size classes from fine to coarse material.

547 The hillslope - stream connectivity can only quantitatively be assessed with automatic 548 measurements of eroded material volumes and particles from the hillslopes at the same (or close)

549 temporal sampling resolution. Our soil erosion measurements adapted from Hancock and Lowry 550 (2015) in combination with a morphometric analysis of soils and sediments provided some 551 evidence of such a hillslope - stream connectivity. However, estimates of erosion rates will need 552 either a process-based model analysis using our preliminary data or a sediment fingerprinting in 553 form of e.g. radioisotope analysis and/or a combination of both to further explore and quantify 554 sediment loads and land-forming processes.

556 This study aimed to gain more insights into the spatio-temporal variability of sediment sources, 557 availability, and transport dynamics in humid tropical volcanic landscapes via intense monitoring. 558 The study emphasized the importance of combined hydro-geomorphic data collection using high 559 temporal resolution sensors and basic synoptic surveys of soil erosion and sediment material 560 properties. In summary, our results indicated that sediment transport dynamics in steep humid 561 tropical volcanic areas, as represented by the study catchment, are highly dynamic by nature 
562 against a background of high but unquantified sediment loads. Generally, sediments were supplied

563 to the stream from the hillslopes in the form of laminar erosion triggered by saturation excess

564 overland flow. However, extreme events with the occurrence of landslides exert an overriding

565 impact on sediment dynamics even with $100 \%$ primary rainforest cover. In response to such an

566 extreme event, runoff-turbidity relationships switched from a non-hysteretic to a strongly

567 hysteretic behaviour after the extreme event. Nevertheless, our results indicated that the system of

568 sediment dynamics was very resilient, as the post-event recovery was relatively quick (around 3

569 months). We also found that during our preliminary monitoring in the tropical, tertiary volcanic

570 environment of the study site, turbidity and discharge are only weak indicators of sediment load

571 and no meaningful discharge - SSC rating curve could be developed (Figure 9). This might limit

572 the use of turbidity data for use of sediment load studies in these environments, but we need more

573 data over much longer measurement periods to be affirmative.

574 We conclude that more studies are needed in tropical, volcanic catchments to provide high-

575 resolution baseline data for process-based model development applied to inform water users such

576 as e.g. hydropower companies about the natural sediment load dynamics and budgets of headwater

577 catchments that provide much of the ecosystem services used downstream. This study provided

578 important first insights into the timing of sediment dynamics and allowed for the formulation of

579 preliminary hypotheses of sediment sources and transport mechanisms. However, to quantify these

580 aspects of hillslope-stream connectivity, we need to combine high temporal resolution monitoring

581 over longer time periods with high spatial resolution erosion and sediment measurements.

582 Remotely sensed imagery from LiDAR-equipped drone applications and radioisotopes for

583 sediment fingerprinting might help in this regard and allow us to quantitatively assess 
584 geomorphological changes to stream networks and their transport rates in tropical, volcanic 585 catchments.

\section{Acknowledgements}

588 A British Geomorphological Society early career grant to JG and CB allowed initiating this work. 589 An Ideawild grant to CB contributed with an equipment donation. The University of Costa Rica 590 Research Council (projects B4239, B8709) supported this project. We thank the ReBAMB staff 591 and students for helping with logistics and fieldwork. The data can be obtained upon request from 592 the corresponding author. 


\section{References}

594 American Public Health Association, American Water Works Association, Water Environment 595 Federation. 1999. Standard methods for the examination of water and wastewater. United States. Bergoeing, J.P., 2007. Geomorphology of Costa Rica. Librería Francesa: San José, Costa Rica.

Birkel, C., Soulsby, C., Tetzlaff, D., 2012. Modelling the impacts of land cover change on streamflow dynamics of a tropical rainforest headwater catchment. Hydrological Sciences

Birkel, C., Geris, J., Molina, M.J., Mendez, C., Arce, R., Dick, J., Tetzlaff, D., Soulsby, C., 2016. Hydroclimatic controls on non-stationary stream water ages in humid tropical catchments. Journal of Hydrology. 542, 231-240. DOI: 10.1016/j.jhydrol.2016.09.006.

Bonell, M., Bruijnzeel, L.A., 2005. Forests, Water and People in the Humid Tropics. Cambridge University Press: Cambridge. DOI: 10.1017/CBO9780511535666.020.

Bracken, L.J.,Wainwright, J., Ali, G.A., Tetzlaff, D., Smith, M.W., Reaney, S.M., Roy, A.G., 2013. Concepts of hydrological connectivity: Research approaches, pathways and future agendas. Earth-Science Reviews. 119, 17-34. DOI: 10.1016/j.earscirev.2013.02.001.

Buendia, C., Vericat, V., Batalla, R.J., Gibbins, C.N., 2015. Temporal dynamics of sediment transport and transient in-channel storage in a highly erodible catchment. Land Degradation \& Development. 27, 1045-1063. DOI: 10.1002/ldr.2348.

Calvo, J., 1998. Suspended sediment yield prediction models for Costa Rican watersheds. International Association of Hydrological Sciences. 253, 27-32.

627 Cheraghi, M., Jomaa, S., Sander, G.C., Barry, D.A., 2016. Hysteretic sediment fluxes in rainfall628 driven soil erosion: Particle size effects. Water Resources Research. 52, 8613-8629. DOI:

$62910.1002 / 2016$ WR019314.

Chow, V.T., 1959. Open channel hydraulics. McGraw-Hill, New York.

634 2018. Spatially distributed tracer-aided modelling to explore water and isotope transport, storage 
635 and mixing in a pristine, humid tropical catchment. Hydrological Processes. 32, 3206- 3224. https://doi.org/10.1002/hyp.13258.

Denyer, P., Montero, W., Alvarado, G.E., 2003. Atlas tectónico de Costa Rica. UCR: San José.

Downing, J.A., Cole, J.J., Duarte, C.M., Middelburg, J.J., Melack, J.M., Prairie, Y.T., Kortelainen, P., Striegl, R.G., McDowell, W.H., Tranvik, L.J., 2012. Global abundance and size distribution of streams and rivers. Inland Waters. 2, 229-236. DOI: 10.5268/IW-2.4.502.

Duvert, C., Gratiot, N., Evrard, O., Navratil, O., Némery, J., Prat, C., Esteves, M., 2010. Drivers of erosion and suspended sediment transport in three headwater catchments of the Mexican Central Highlands. Geomorphology. 123, 243-256. DOI: 10.1016/j.geomorph.2010.07.016.

Fagan, M.E., DeFries, R.S., Sesnie, S.E., Arroyo, J.P., Walker, W., Soto, C., Chazdon, R.L., Sanchun, A., 2013. Land cover dynamics following a deforestation ban in northern Costa Rica. Environmental Research Letters. 8. DOI: 10.1088/1748-9326/8/3/034017.

Foley, J.A., DeFries, R., Asner, G.P., Barford, C., Bonan, G., Carpenter, S.R., Chapin, F.S., Coe, M.T., Daily, G.C., Gibbs, H.K., Helkowsky, J.H., Holloway, T., Howard, E.A., Kucharik, C.J., Monfreda, C., Patz, J.A., Prentice, C., Ramankutty, N., Snyder, P.K., 2005. Global Consequences of Land Use. Science. 309. DOI: 10.1126/science.1111772.

Fryers, K., 2013. (Dis)Connectivity in catchment sediment cascades: a fresh look at the sediment delivery problem. Earth Surface Processes and Landforms. 38, 30-46. DOI: 10.1002/esp.3242.

Giorgi, F. 2006. Climate change hot-spots. Geophysical Research Letters. 33. DOI: 10.1029/2006GL025734.

González, J.E., Georgescu, M., Lemos, M.C., Hosannah, N., Niyogi, D., 2017. Climate change's pulse is in Central America and the Caribbean. Eos 98. DOI: 10.1029/2017EO071975. Hancock, G.R., Lowry, J.B.C., 2015. Hillslope erosion measurement --a simple approach to a complex process. Hydrological Processes. 29, 4809-4816. DOI: 10.1002/hyp.10608.

Henríquez, C., Cabalceta, G., 2012. Guía práctica para el estudio introductorio de los suelos con un enfoque agrícola. Costa Rican Association of Soil Science: San José.

Hudson, P.F., 2003. Event sequence and sediment exhaustion in the lower Panuco Basin, Mexico. Catena. 52, 57-76. DOI: 10.1016/S0341-8162(02)00145-5.

Jansson, M., 2002. Determining sediment source areas in a tropical river basin, Costa Rica. Catena. 47, 63-84.

Krishnaswamy, J., Halpin, P.N., Richter, D.D., 2001a. Dynamics of sediment discharge in relation to land-use and hydro-climatology in a humid tropical watershed in Costa Rica. Journal of Hydrology. 253, 91-109. DOI: 10.1016/S0022-1694(01)00474-7. 
Krishnaswamy, J., Richter, D., Halpin, P., Hofmockel, M., 2001b. Spatial patterns of suspended sediment yields in a humid tropical watershed in Costa Rica. Hydrological Processes. 5, 22372257. DOI: 10.1002/hyp.230.

Labrière, N., Locatelli, B., Laumonier, Y., Freycon, V., Bernoux, M., 2015. Soil erosion in the humid tropics: A systematic quantitative review. Agriculture, Ecosystems \& Environment. 203, 127-139. DOI: 10.1016/j.agee.2015.01.027.

Loescher, H.W., Powers, J.S., Oberbauer, S.F., 2002. Spatial variation of throughfall volume in an old-growth tropical wet forest, Costa Rica. Journal of Tropical Ecology. 18, 397-407. DOI: $10.1017 / \mathrm{S} 0266467402002274$.

López-Tarazón, J.A., Estrany, J., 2017. Exploring suspended sediment delivery dynamics of two Mediterranean nested catchments. Hydrological Processes. 31, 698- 715.

DOI: $10.1002 /$ hyp.11069.

Martínez-Mena, M., Alvarez-Rogel, J., Albaladejo, J., Castillo, V., 1999. Influence of vegetal cover on sediment particle size distribution in natural rainfall conditions, in a semiarid environment. Catena. 38, 175-190.

Mills, C.F., Bathurst, J.C., 2015. Spatial variability of suspended sediment yield in a gravel-bed river across four orders of magnitude of catchment area. Catena. 133, 14-24. https://doi.org/10.1016/j.catena.2015.04.008.

Muñoz-Villers, L.E., McDonnell, J.J., 2012. Runoff generation in a steep, tropical montane cloud forest catchment on permeable volcanic substrate. Water Resources Research. 48. DOI: 10.1029/2011WR011316.

NOAA., 2016. http://www.cpc.ncep.noaa.gov/products/analysis_monitoring/ensostuff/ensoyears.shtml (last visited July 2017).

711 R Development Core Team. 2016. R: A Language and Environment for Statistical Computing. R 712 Foundation for Statistical Computing: Vienna.

Norambuena, P., Luzio, W., Vera, W., 2002. Comparison between the pipette and bouyoucos methods and their relation with water retention in eight soils of the andean plateau, Parinacota Province, Chile. Agricultura Técnica. 62. DOI: 10.4067/S0365-28072002000100015.

Perks, M.T., Owen, G.J., Benskin, C.M., Jonczyk, J., Deasy, C., Burke, S., Reaney, S.M., Haygarth, P.M., 2015. Dominant mechanisms for the delivery of fine sediment and phosphorus to fluvial networks draining grassland dominated headwater catchments. Science of the Total Environment. 523, 178-190. DOI: 10.1016/j.scitotenv.2015.03.008. 
Rovira, A., Batalla, R.J., 2006. Temporal distribution of suspended sediment transport in a Mediterranean basin: The Lower Tordera (NE Spain). Geomorphology. 79, 58-71. DOI: 10.1016/j.geomorph.2005.09.016.

717 Salazar-Rodríguez, A.H., 2003. Reserva Biológica Alberto Manuel Brenes: Una excepción en 718 Costa Rica. Revista InterSedes 8.

Shanley, J.B., McDowell, W.H., Stallard, R.F., 2011. Long-term patterns and short-term dynamics of stream solutes and suspended sediment in a rapidly weathering tropical watershed. Water Resources Research. 47. DOI: 10.1029/2010WR009788.

Sharon, D., 1980. The distribution of hydrologically effective rainfall incident on sloping ground. Journal of Hydrology. 46, 165-188. DOI: 10.1016/0022-1694(80)90041-4.

Thomas, MF., 1994. Geomorphology in the Tropics: A Study of Weathering and Denudation in Low Latitudes. John Wiley and Sons: Chichester.

Tricart, J., 1965. Principes et méthodes de la géomorphologie. Masson et Cie Éditeurs: Paris.

Vargas, G., 1978. Diagnóstico y recomendaciones para el manejo y ordenamiento de los recursos naturales de la cuenca del río San Lorenzo, Alajuela, Costa Rica (unpublished thesis). University of Costa Rica.

Veas, N., 2009. Caracterización y estimación de la erosión laminar en un bosque pre-montano a partir de un modelado hidrológico. Microcuenca del río San Lorencito, Cordillera Volcánica de Tilarán, Costa Rica. (unpublished thesis). University of Costa Rica.

Walsh, R.P.D., Bidin, K., Blake, W.H., Chappell, N.A., Clarke, M.A., Douglas, I., Ghazali, R., Sayer, A.M., Suhaimi, J., Tych, W., Annammala, K.V., 2011. Long-term responses of rainforest erosional systems at different spatial scales to selective logging and climatic change. Philosophical Transactions of the Royal Society London B Biological Sciences. 366 (1582), 3340-3353. DOI: 10.1098/rstb.2011.0054.

Wohl, E., Barros, A., Brunsell, N., Chappell, N., Coe, M., Giambelluca, T., Goldsmith, S., Harmon, R., Hendrickx, J., Juvik, J., McDonnell, J., Ogden, F., 2012. The hydrology of the humid tropics. Nature Climate Change. 2, 655-662. DOI: 10.1038/nclimate1556.

Zhang, Z., Tao, F., Shi, P., Xu, W., Sun, Y., Fukushima, T., Onda, Y., 2010. Characterizing the flush of stream chemical runoff from forested watersheds. Hydrological Processes. 24(20), 2960 - 2970. DOI: 10.1002/hyp.7717.

Ziegler, S.G. Benner, C. Tantasirin, S.H. Wood, R.A. Sutherland, R.C. Sidle, N.R.A. Jachowski, X. Lu, A. Snidvongs, T.W. Giambelluca, J.M. Fox. 2014. Turbidity-based sediment monitoring in northern Thailand: hysteresis, variability, and uncertainty. Journal of Hydrology. DOI: 10.1016/j.jhydrol.2014.09.010. 
753 Zimmermann, A., Francke, T., Elsenbeer, H., 2012. Forests and erosion: Insights from a study of 754 suspended-sediment dynamics in an overland flow-prone rainforest catchment. Journal of 755 Hydrology. 27, 170-181. DOI: 10.1016/j.jhydrol.2012.01.039.

756

757

Zuecco, G., Penna, D., Borga, M., van Meerveld, H.J., 2016. A versatile index to characterize 758 hysteresis between hydrological variables at the runoff event timescale. Hydrological Processes.

759 30, 1449-1466. DOI: 10.1002/hyp.10681.

760

761

762

763

764

765

766

767

768 
TABLES

Table I. Basic catchment descriptors and data properties for hydro-meteorological and

772 geomorphologic context.

\begin{tabular}{l|l|l|}
\hline Descriptor & Unit & Mean [Range] \\
\hline Area & $\mathrm{km}^{2}$ & 3.2 \\
\hline Topography & & \\
Elevation & $\mathrm{m}$. a.s.l. & $1133.5[873.7-1472.4]$ \\
Slope & $\circ$ & $22.3[0.15-52]$ \\
Drainage Density (1:200000) & $\mathrm{km} / \mathrm{km}^{2}$ & 0.016 \\
Stream Slope & $\circ$ & 20.5 \\
Sediment Transport Index & & $17.04[0-390]$ \\
Terrain Ruggedness Index & & $1.63[0.01-5.03]$ \\
\hline Hydroclimatic & & \\
Annual P 2015-2016 & $\mathrm{mm}$ & 2762 \\
Annual PET 2015-2016 & $\mathrm{mm}$ & 425 \\
Annual Q 2015-2016 & $\mathrm{mm}$ & 2448 \\
\hline
\end{tabular}

773

774

775

776

777

778

779

780

781

782

783 
784 Table II. The hydro-meteorological characteristics (8 variables) of the selected rainfall events

785 during the study period (co-linear variables were removed) plus the hysteresis index of Zuecco et

786 al. (2016) and classification are shown. The four events marked in italics were used for further

787 analysis and note that the second (extreme) event marks the pre- and post-event periods used in

788 the analysis. The mean and standard deviation was calculated without the August 2015 extreme

789 event. The selected variables were a 7-day Antecedent Wetness Index $-A W I 7 d$, rainfall magnitude

$790 M$, maximum rainfall intensity - Imax, discharge event range $-Q$ range, lag time from rainfall

791 peak to discharge peak - $P_{-}$Qlag, turbidity event range - Range, lag time from rainfall peak to

792 turbidity peak $-P_{-}$TUlag, lag time from turbidity peak to discharge peak - TU_Qlag.

\begin{tabular}{|c|c|c|c|c|c|c|c|c|c|c|}
\hline Event Date & $\begin{array}{l}\text { AWI7d } \\
(\mathbf{m m})\end{array}$ & $\begin{array}{l}\mathbf{M} \\
(\mathbf{m m})\end{array}$ & $\begin{array}{l}\operatorname{Imax} \\
(\mathrm{mm} / \mathrm{h})\end{array}$ & $\begin{array}{l}Q \text { range } \\
\left(\mathbf{m}^{3} / \mathbf{s}\right)\end{array}$ & $\begin{array}{l}\text { P_Qlag } \\
\text { (h) }\end{array}$ & $\begin{array}{l}\text { Range } \\
\text { (NTU) }\end{array}$ & $\begin{array}{l}\text { P_TUla } \\
\text { g (h) }\end{array}$ & $\begin{array}{l}\text { TU_Qlag } \\
\text { (h) }\end{array}$ & $\begin{array}{c}\text { Hyst } \\
\text { index }\end{array}$ & $\begin{array}{l}\text { Hyst } \\
\text { Class }\end{array}$ \\
\hline $13-14 / 6 / 2015$ & 74.89 & 13.21 & 13.21 & 0.34 & 1 & 587.66 & 6 & 6 & 0.063 & 2 \\
\hline $16-18 / 6 / 2015$ & 68.55 & 29.71 & 8.64 & 1.16 & 1 & 998.08 & 2.5 & 1.5 & $*$ & $*$ \\
\hline 1) $19-20 / 6 / 2015$ & 59.4 & 8.38 & 3.58 & 0.69 & 1.5 & 69.09 & 2.5 & 1 & $*$ & $*$ \\
\hline $24-25 / 6 / 2015$ & 58.87 & 22.05 & 7.36 & 0.79 & 7 & 413.01 & 8.5 & 1.5 & $*$ & $*$ \\
\hline $26 / 6 /-2 / 7 / 2015$ & 75.84 & 26.63 & 3.55 & 1.26 & 13.5 & 463.3 & 13.5 & 0 & 0.036 & 2 \\
\hline $7-8 / 7 / 2015$ & 42.81 & 38.08 & 19.3 & 3.08 & 3.5 & 204.4 & 0.5 & 0.5 & 0.065 & 2 \\
\hline $10-11 / 7 / 2015$ & 91.26 & 28.95 & 18.54 & 0.75 & 1 & 84.24 & 3.5 & 2.5 & $*$ & * \\
\hline $14-15 / 7 / 2015$ & 127.32 & 2.78 & 2.03 & 1.69 & 2 & 786.55 & 2.5 & 0.5 & 0.576 & 4 \\
\hline $19-21 / 7 / 2015$ & 39.5 & 25.13 & 22.1 & 4.2 & 1 & 580.82 & 4 & 3 & 0.098 & 4 \\
\hline $29-30 / 7 / 2015$ & 29.11 & 56.65 & 27.43 & 17.25 & 0.5 & 704.43 & -3.5 & -2 & 0.545 & 1 \\
\hline $8-10 / 8 / 2015$ & 24.53 & 132.33 & 40.13 & 4.99 & 2.5 & 813.05 & 2.5 & 0 & 0.341 & 1 \\
\hline 2) $10-11 / 8 / 2015$ & 158.64 & 98.57 & 77.22 & 343.77 & 0 & 974.06 & 1 & 1 & 0.126 & 1 \\
\hline $31 / 8-1 / 9 / 2015$ & 8.61 & 59.19 & 29.72 & 1.75 & 0.5 & 929.61 & 1.5 & 1 & 0.124 & 3 \\
\hline $11-12 / 9 / 2015$ & 55.34 & 44.95 & 32.51 & 9.62 & 1 & 760.64 & 7.5 & 6.5 & 0.11 & 1 \\
\hline $13-14 / 9 / 2015$ & 106.89 & 38.1 & 29.47 & 3.89 & 1.5 & 636.58 & 0.5 & -1 & 0.186 & 2 \\
\hline $17-18 / 09 / 2015$ & 93.93 & 10.16 & 9.66 & 1.4 & 1 & 762 & 2 & 1 & -0.32 & 4 \\
\hline $19-20 / 09 / 2015$ & 56.82 & 4.32 & 4.07 & 1.34 & 0.5 & 854.2 & 3 & 2.5 & 0.558 & 4 \\
\hline $20-21 / 09 / 2015$ & 22.03 & 10.92 & 6.61 & 0.8 & 1 & 425 & 2.5 & 1.5 & 0.039 & 2 \\
\hline $21-22 / 09 / 2015$ & 32.2 & 48.01 & 32.52 & 14.3 & 1 & 722.1 & 1 & 0 & 0.127 & 1 \\
\hline $22-23 / 09 / 2015$ & 80.96 & 35.05 & 25.4 & 3.73 & 0.5 & 939.1 & 4 & 3.5 & 0.205 & 2 \\
\hline 3) $27-28 / 09 / 2015$ & 126.67 & 34.79 & 33.02 & 6.68 & 0.5 & 877.4 & 7 & 6.5 & 0.036 & 1 \\
\hline $12-13 / 10 / 2015$ & 76.82 & 8.64 & 5.59 & 1.11 & 1 & 906.9 & 9.5 & 8.5 & 0.213 & 5 \\
\hline $16-18 / 10 / 2015$ & 76.61 & 49.77 & 26.67 & 10.7 & 1.5 & 327.5 & 0 & -1.5 & 0.215 & 1 \\
\hline $20-23 / 10 / 2015$ & 90.59 & 50.3 & 21.59 & 7.03 & 7.5 & 636.8 & 1.5 & -6 & 0.033 & 2 \\
\hline $05-07 / 11 / 2015$ & 28.39 & 35.56 & 19.56 & 4.33 & 0.5 & 508.2 & 0.5 & 0 & 0.086 & 2 \\
\hline $\begin{array}{l}31 / 12 / 2015- \\
02 / 01 / 2016\end{array}$ & 8.59 & 19.29 & 4.83 & 0.76 & 2.5 & 997.2 & 4.5 & 2 & 0.628 & 4 \\
\hline $27 / 4 / 2016$ & 6.59 & 45.22 & 40.39 & 0.47 & 1 & 57.9 & 6 & 5 & 0.32 & 6 \\
\hline 4) $26-27 / 5 / 2016$ & 9.33 & 12.69 & 11.68 & 1.12 & 1.5 & 222.42 & 1.5 & 0 & 0.064 & 2 \\
\hline $31 / 5-2 / 6 / 2016$ & 34.73 & 35.56 & 31.5 & 2.72 & 1 & 191.77 & 0.5 & -1 & 0.016 & 3 \\
\hline Mean: & 57.4 & 33.1 & 18.9 & 3.9 & 2.1 & 587.9 & 3.4 & 1.5 & & \\
\hline
\end{tabular}




\begin{tabular}{|l|r|r|r|r|r|r|r|r|l|l|}
\hline Std. Dev.: & 35.0 & 25.4 & 12.1 & 4.4 & 2.8 & 298.6 & 3.5 & & 3.0 & \\
\hline
\end{tabular}

793 *no hysteretic behaviour detected.

794

795

796

797

798

799

800

801

802

803

804

805

806

807

808

809

810

811

812

813

814

815

816

817

818

819

820

821

822

823

824

825

826

827

828

829

830

831

832 
833 Table III. Pre-event (upper panel in Grey italics) and post-event (lower panel in black)

834 Spearman rank correlation matrix of eight selected rainfall-runoff-turbidity parameters.

835 Statistical significance is given by asterisks $(*=90 \%, * *=95 \%$ and $* * *=99 \%)$.

\begin{tabular}{|c|c|c|c|c|c|c|c|c|}
\hline & $\begin{array}{c}\text { AWI7d } \\
(\mathrm{mm})\end{array}$ & $\begin{array}{c}\mathrm{M} \\
(\mathrm{mm})\end{array}$ & $\begin{array}{c}\text { Imax } \\
(\mathrm{mm} / \mathrm{h})\end{array}$ & $\begin{array}{c}\text { Qrange } \\
\left(\mathrm{m}^{3} / \mathrm{s}\right)\end{array}$ & $\begin{array}{c}\text { P_Qlag } \\
\text { (h) }\end{array}$ & $\begin{array}{l}\text { Range } \\
\text { (NTU) }\end{array}$ & $\begin{array}{c}\text { P_TUlag } \\
\text { (h) }\end{array}$ & $\begin{array}{c}\text { TU_Qlag } \\
\text { (h) }\end{array}$ \\
\hline $\begin{array}{l}\text { AWI7d } \\
(\mathrm{mm})\end{array}$ & 1 & $-0.61(*)$ & $-0.84(* *)$ & -0.66 (*) & 0.13 & -0.19 & 0.34 & 0.27 \\
\hline $\begin{array}{c}\mathrm{M} \\
(\mathrm{mm})\end{array}$ & -0.01 & 1 & 0.81 (**) & $0.58(*)$ & -0.19 & 0.33 & -0.46 & -0.42 \\
\hline $\begin{array}{c}\text { Imax } \\
(\mathrm{mm} / \mathrm{h})\end{array}$ & 0.1 & $0.71(* *)$ & 1 & $0.65(*)$ & -0.41 & 0.22 & -0.4 & -0.1 \\
\hline $\begin{array}{l}\text { Qrange } \\
\left(\mathrm{m}^{3} / \mathrm{s}\right)\end{array}$ & 0.47 & $0.63(* *)$ & 0.48 & 1 & -0.17 & 0.58 (*) & -0.42 & -0.52 \\
\hline $\begin{array}{c}\text { P_Qlag } \\
\text { (h) }\end{array}$ & -0.13 & 0.36 & -0.1 & -0.03 & 1 & -0.19 & 0.44 & -0.24 \\
\hline $\begin{array}{l}\text { Range } \\
\text { (NTU) }\end{array}$ & 0.4 & -0.42 & -0.38 & 0.01 & -0.23 & 1 & -0.19 & -0.27 \\
\hline $\begin{array}{c}\text { P_TUlag } \\
\text { (h) }\end{array}$ & -0.01 & -0.4 & -0.07 & -0.4 & -0.28 & $0.56\left({ }^{*}\right)$ & 1 & 0.45 \\
\hline $\begin{array}{c}\text { TU_Qlag } \\
\text { (h) }\end{array}$ & -0.04 & -0.48 & -0.03 & -0.38 & $-0.54(*)$ & $0.52(*)$ & $0.93(* * *)$ & 1 \\
\hline
\end{tabular}

836

837

838

839 


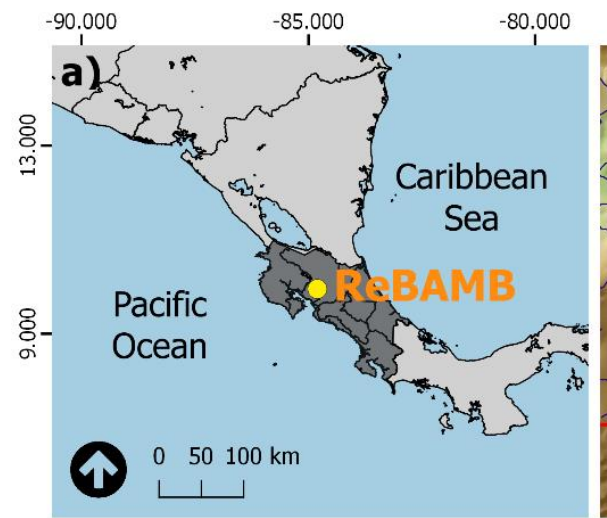

d)

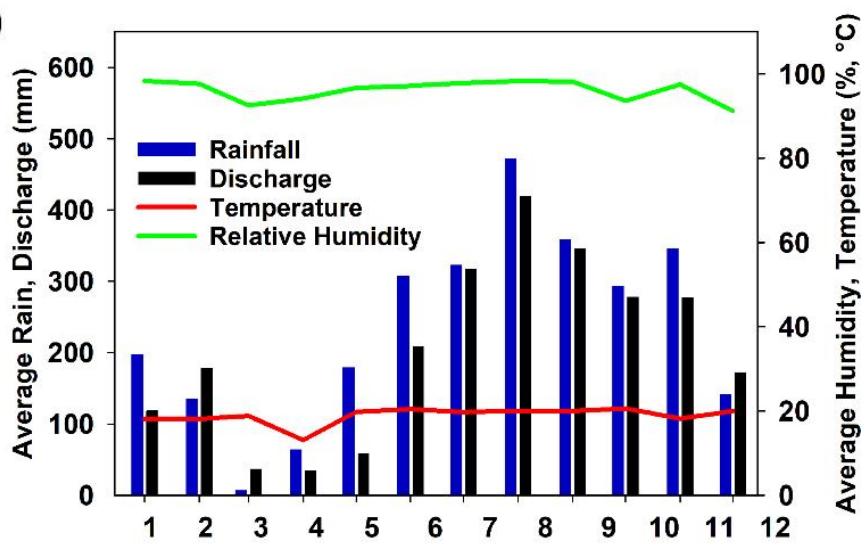

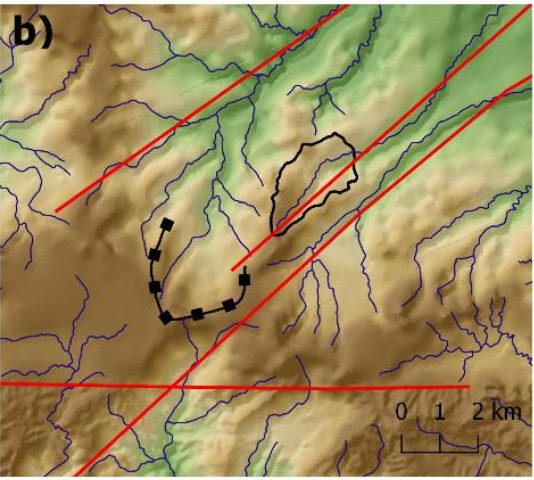

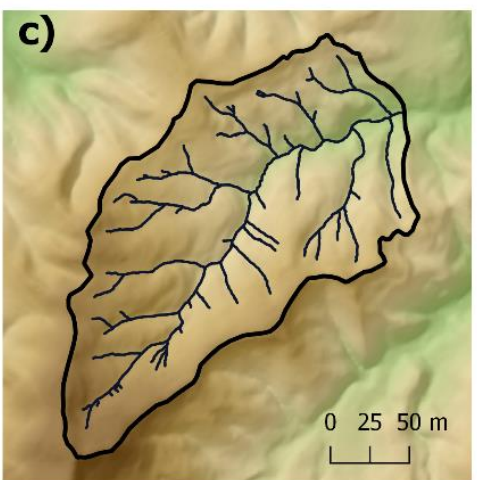

e)

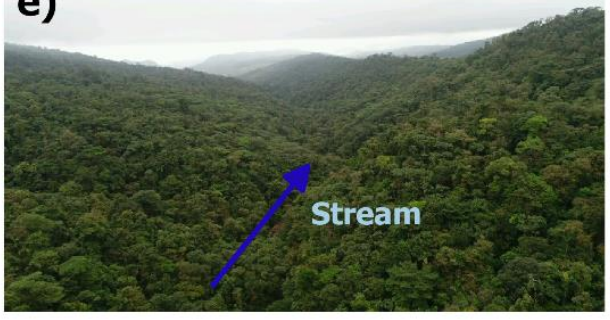

Symbology

— Normal Faults

- Volcanic Tertiary Structure - Streams

842 Figure 1. a) Regional context showing the location of the San Lorencito catchment in Costa Rica,

843 Central America with b-c) topography, volcanic, and tectonic geological features (fault lines and

844 the tertiary volcano remnant) that affect sediment dynamics (Denyer et al., 2003), d) monthly

845 climate regime from January to December (1 to 12) based on the measurements of 2015-2016, and e) aerial image of the dense rainforest. 


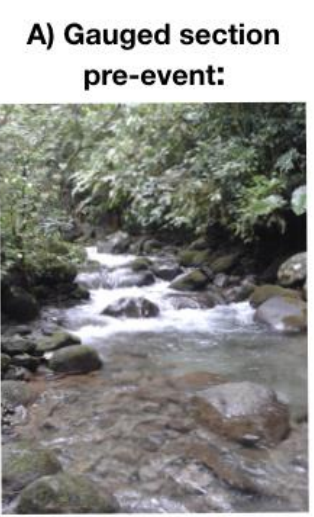

C) Gauged section normal flow:

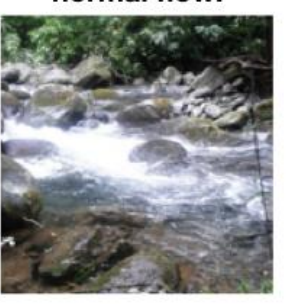

B) Gauged section post-event:

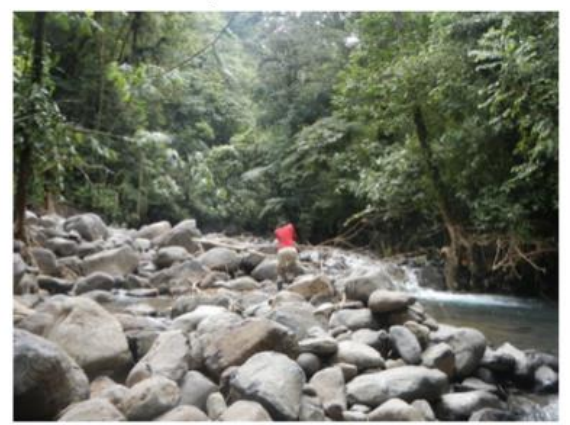

D) Gauged section high flow:

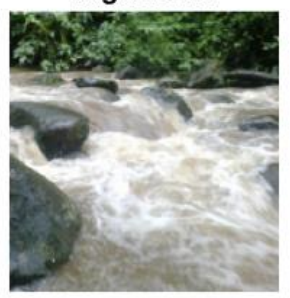

E) Pre and post-event channel changes:

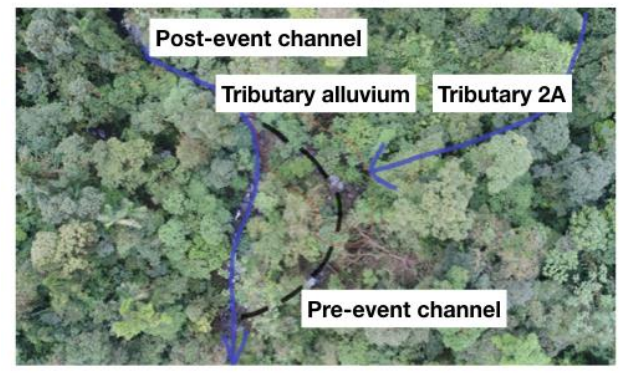

F) River bank:

G) Post-event landslide:

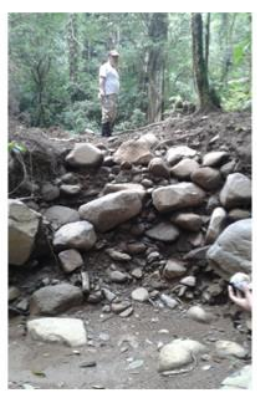

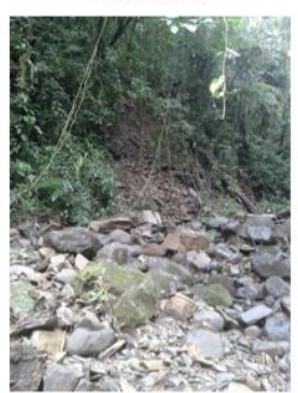

849 Figure 2. A and B) The pre-event step-pool stream morphology looking upstream from the gauged

850 section and the widened post-event section with material deposits. C and D) show the flow in

851 normal conditions and high flow with turbid water. E) Reconstructed stream channel modifications

852 and the tributary influence in contributing alluvial material. F) Post-event eroded stream bank

853 showing the previously deposited fluvial material. G) Post-event landslide incorporating fresh 854 material into the stream. 


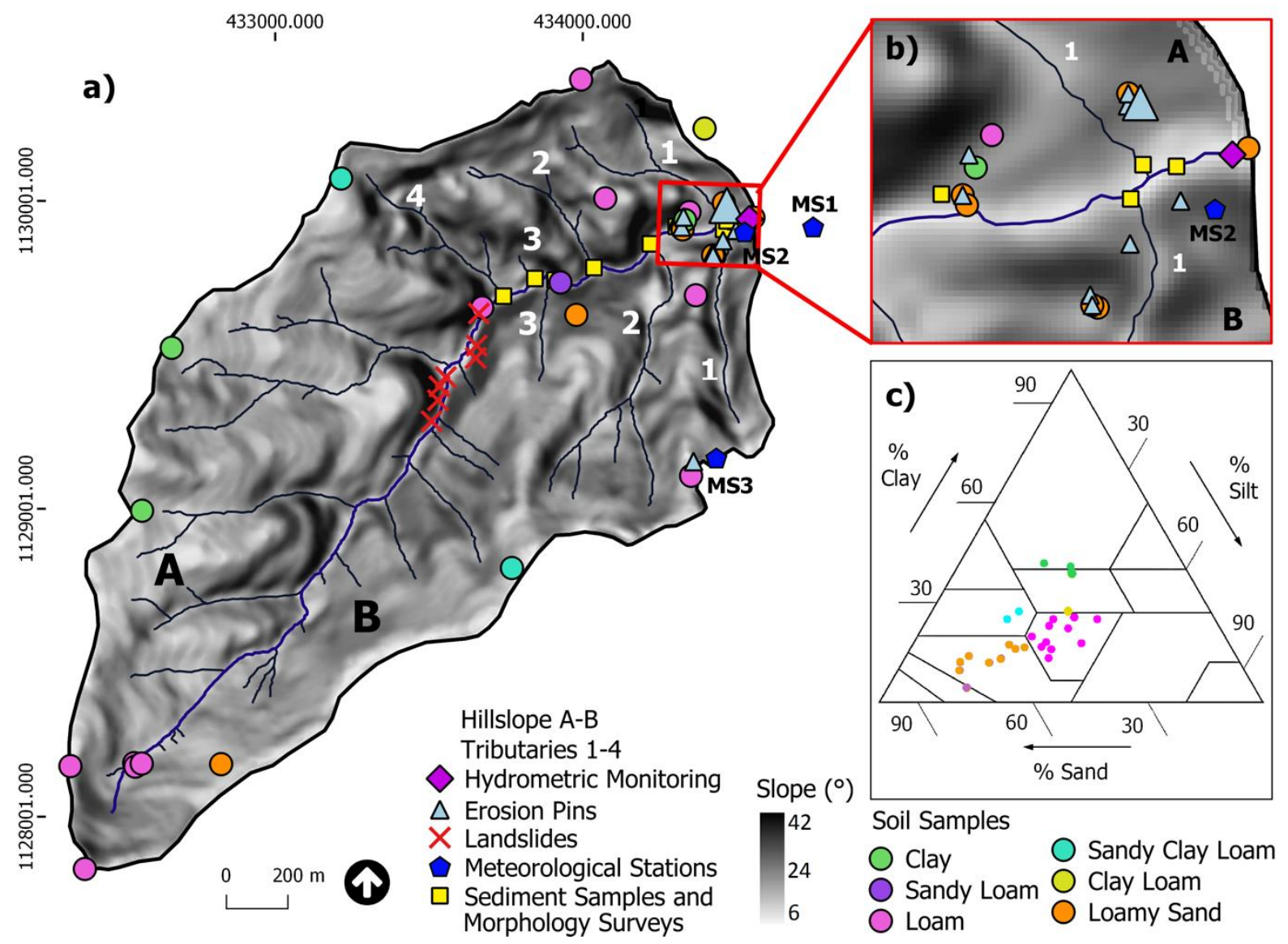

856 Figure 3. a) The slope map (grey scale) shows the location of monitoring equipment

857 (hydrometric and meteorological stations MS with MS1 recording gross precipitation and MS2

858 and MS3 throughfall) and spatial surveys, b) the detailed map indicates the locations of soil,

859 erosion (larger triangle shows the largest soil erosion measurement), landslides and sediment

860 surveys dictated by site access, and c) the distribution of the processed and colour coded soil

861 samples across the United States Department of Agriculture (USDA) texture triangle. 


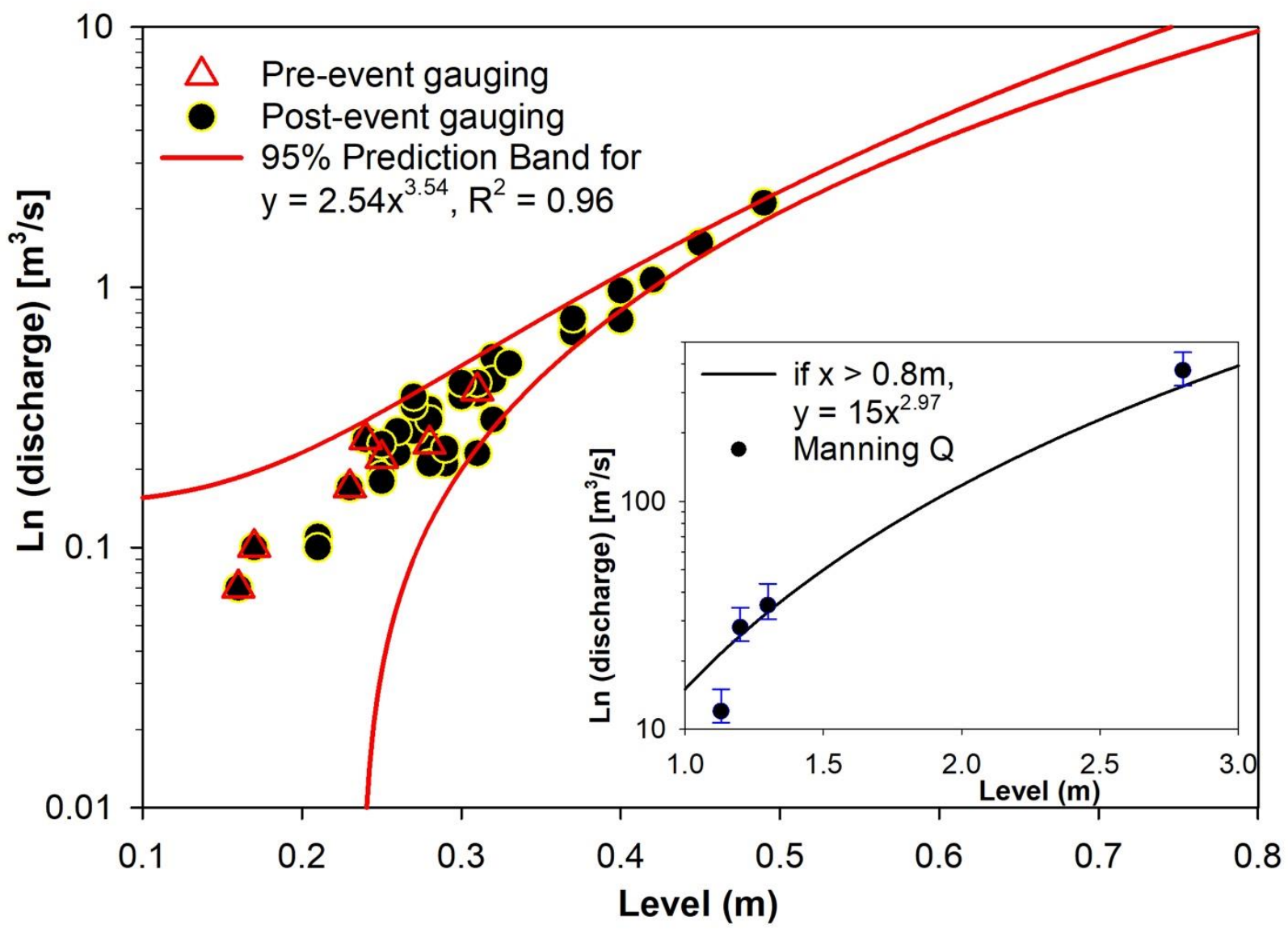

863 Figure 4. The preliminary two-stage rating curve for the San Lorencito stream based on 37

864 manual gaugings (7 pre-event in red triangles and 30 post-event in yellow-black circles) and four

865 re-constructed largest peak flows with overbank flow using Manning's equation (inlet graph).

866 The error bars were calculated systematically varying Manning's n roughness coefficient. 

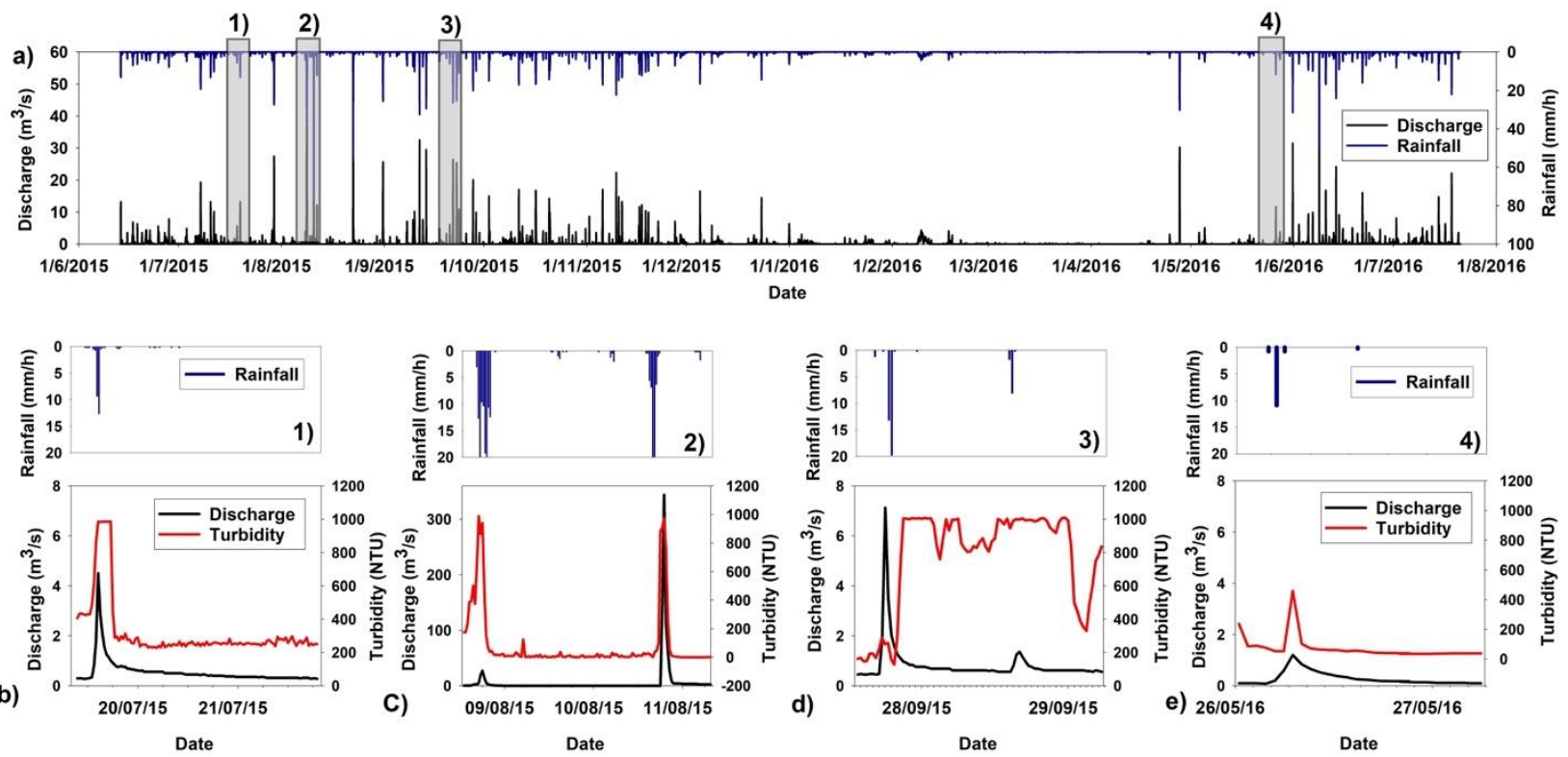

Figure 5. a-b) Average hourly rainfall-runoff time series for the study period with four selected events marked with grey bars emphasizing the discharge-turbidity dynamics during 1) the rainy season before the extreme event, 2) the major event in August 2015, 3) post-event during the rainy

871 season and 4) at the beginning of the rainy season in May 2016. All scales are comparable apart

872 from the major event (2) occurred in August 2015 showing a different scale for visualization

873 purposes. 

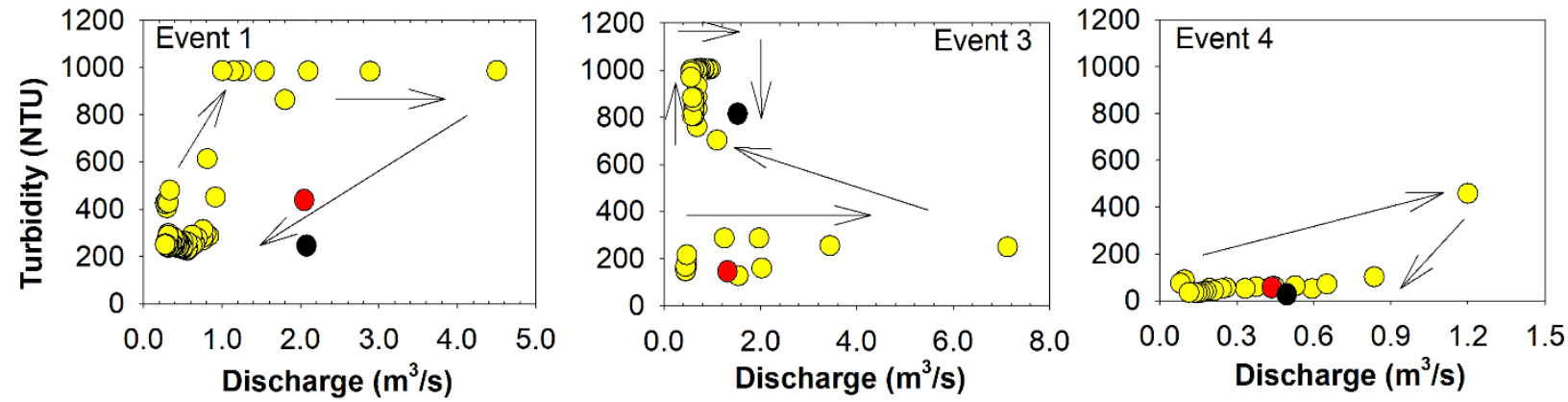

881 Figure 6. Discharge - turbidity hysteresis plots for pre-flood event (event 1 in Figure 4) conditions

882 (clockwise hysteresis), post-flood event (event 3 - anti-clockwise and eight-shaped hysteresis) and

883 recovery conditions (event 4 - clockwise hysteresis). The turbidity scale is comparable for

884 visualization purposes and the numbering of events corresponds to Figure 4. Red dots mark the

885 starting discharge and turbidity, black dots indicate the end of the event and the arrows give the 886 hysteresis direction. 


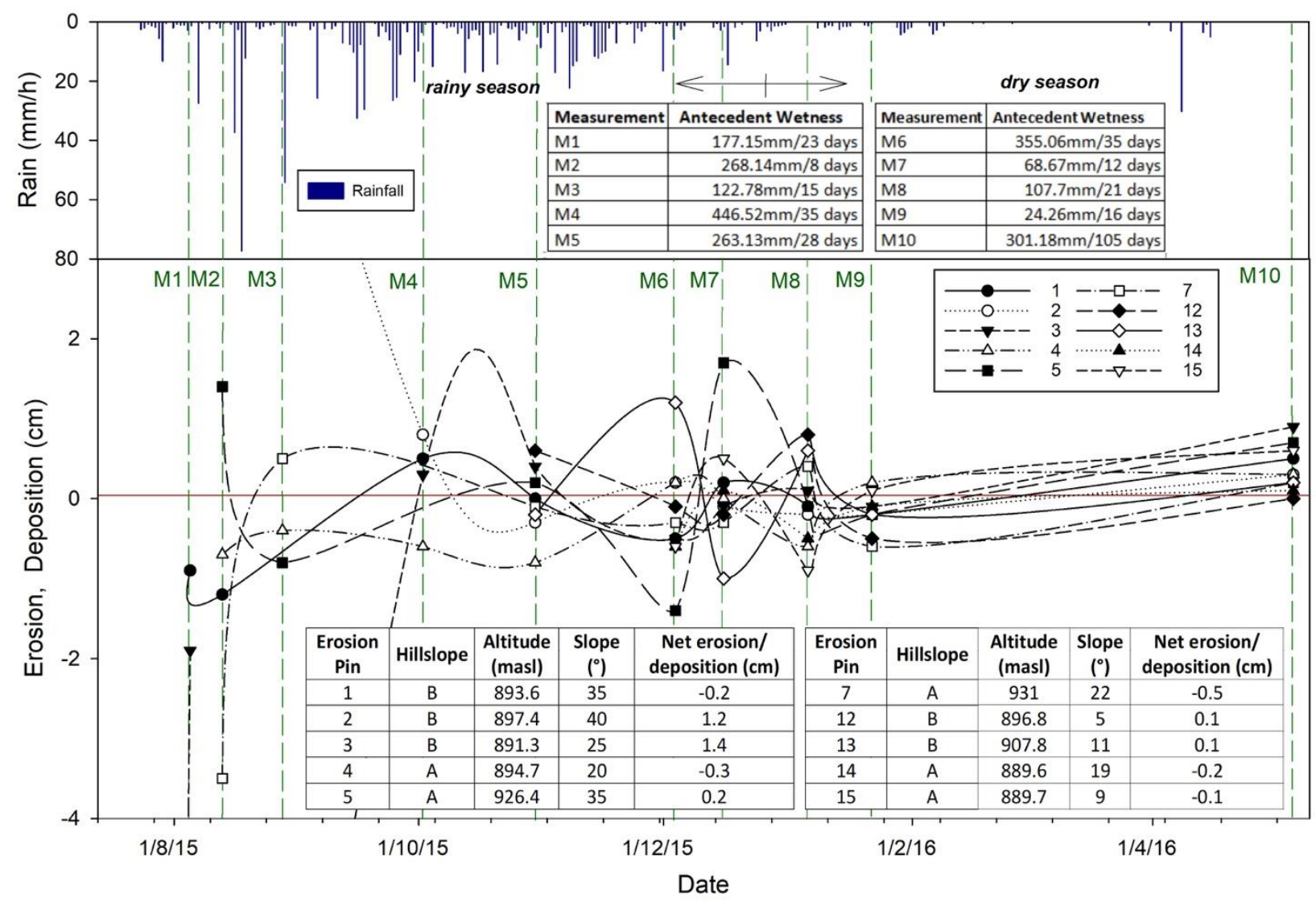

897 Figure 7. Soil movement was detected using erosion pins for the study period 2015-16 with the

898 sites (see Figure 2) main physical characteristics (slope and altitude) and the accumulated rainfall

899 between measurements. Negative values represent erosion and positive values represent

900 deposition (accumulation of material). The measurements were connected with smoothed lines to

901 emphasize the temporal variability over the roughly monthly interval. Erosion pin 3 showed the

902 largest soil erosion and pin 2 the largest deposition (both on hillslope B). 

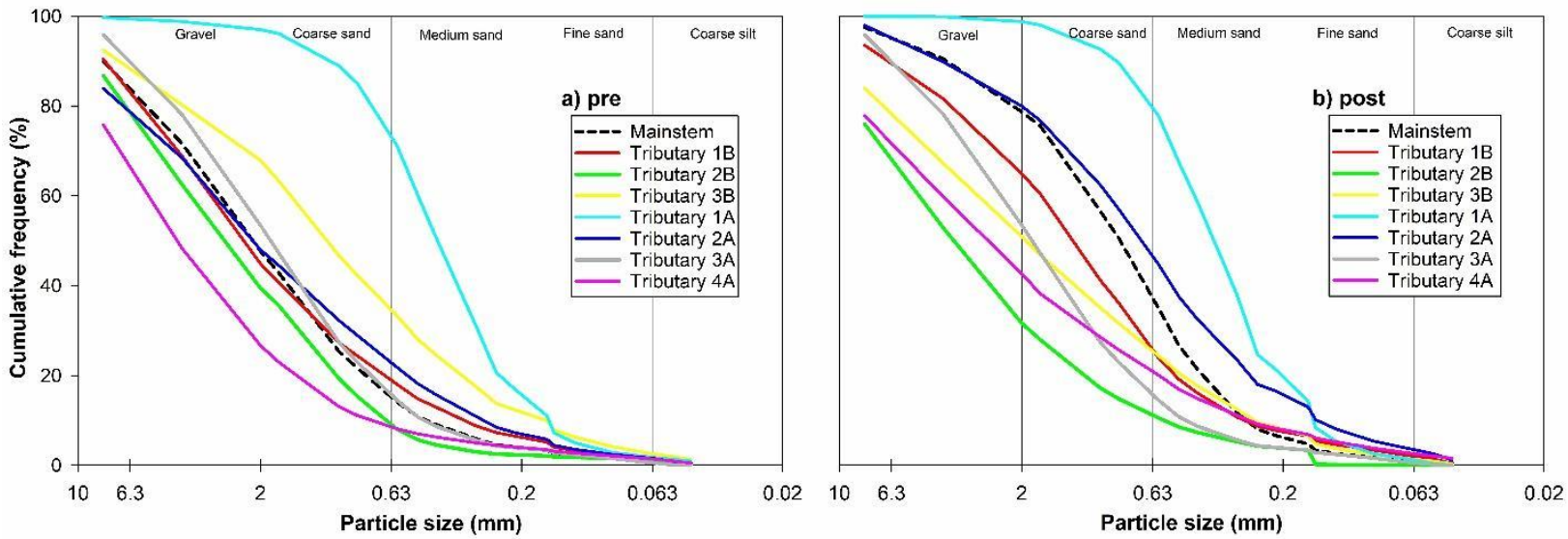

903

904 Figure 8. The figure shows the particle size distributions of stream sediments sampled a) before

905 and b) after the major flood event across the drainage network and tributaries as indicated in

906 Figure 2 (A, B corresponds to the hillslope location and the increasing numbering of upstream

907 tributaries). 

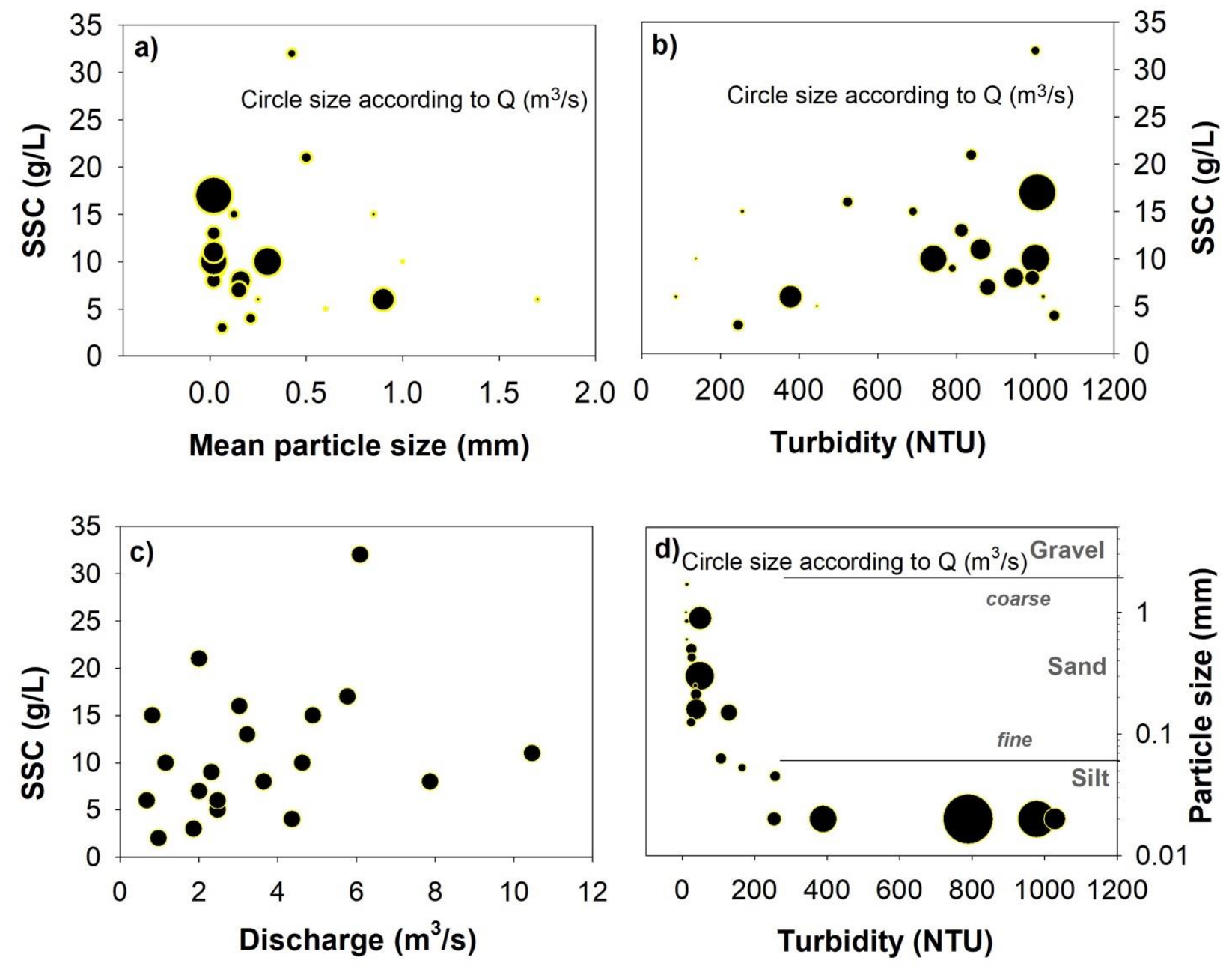

908

909 Figure 9. a) the mean particle size - suspended sediment concentration (SSC in g/L) - discharge

910 (Q) visualization from 0.2 to $10 \mathrm{~m}^{3} / \mathrm{s}$ is plotted for 23 storm event samples and b) the SSC and

911 turbidity level.

912

913

914

915 


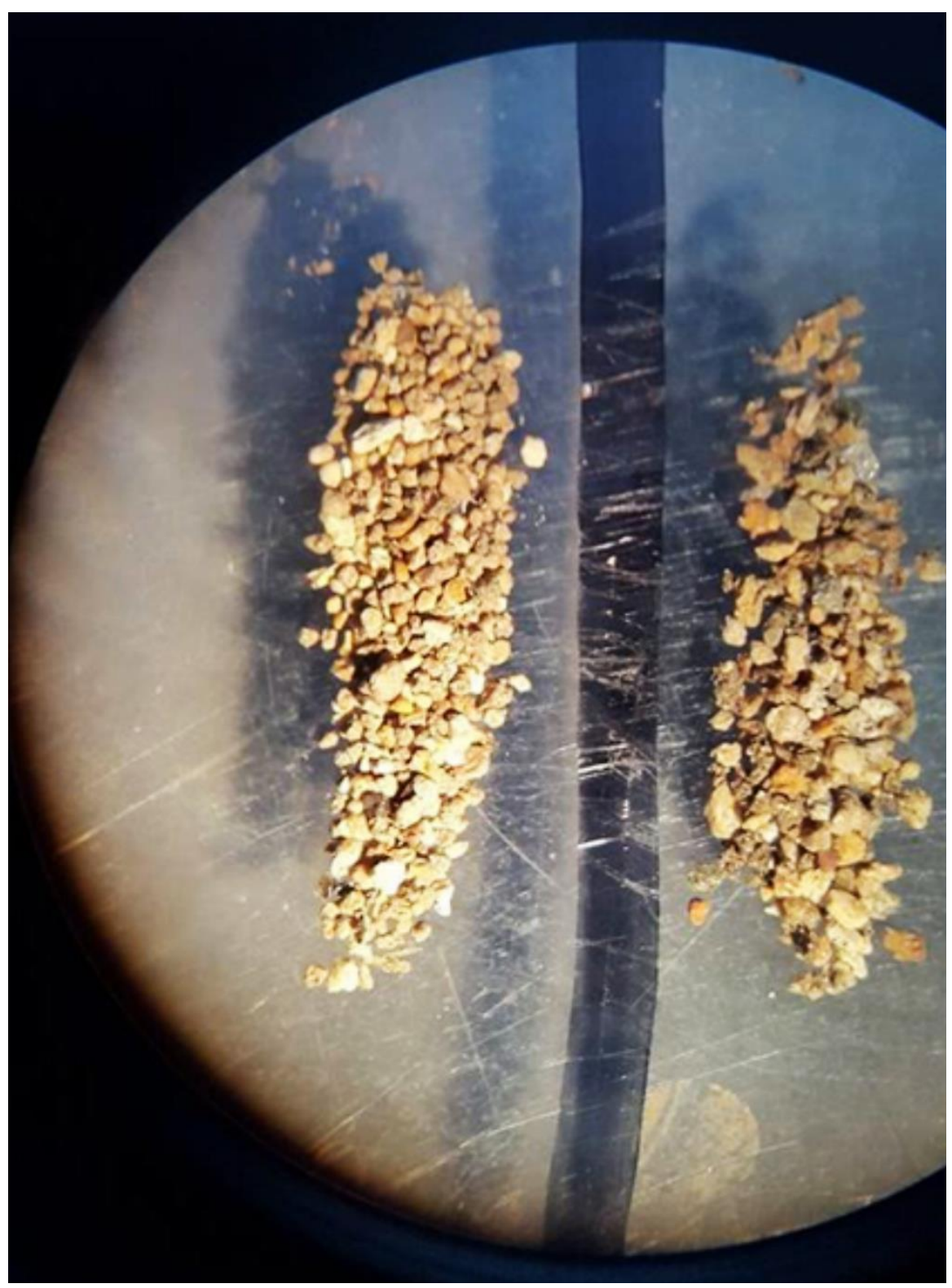

917

918 Figure S1. Direct stereo microscope comparison of fine sands material properties (angle, oxidation

919 level) recovered from an exemplary soil sample (left hand side) and stream sediment sample of

920 tributary 1B (right hand side). Note that the soil sample was taken from within the contributing

921 sub-catchment area of tributary 1B and shows almost identical mineralogy in support of a

922 hillslope-stream connectivity. 